\title{
Influence of Operating Parameters on Slurry Erosion of Stainless Steel F6NM
}

\author{
I.A. Maekaia, G.A. Harmaina,* \\ a Turbine Erosion Testing Lab, Department of Mechanical Engineering, National Institute of Technology, Srinagar \\ 190006, Kashmir, India.
}

Keywords:

F6NM

Slurry Erosion

Response Surface Methodology

Erodent Particles

Hydro Turbine

* Corresponding author:

G.A. Harmain

E-mail:gharmain@nitsri.net

Received: 19 October 2019

Revised: 9 December 2019

Accepted: 20 February 2020

\section{A B S T R A C T}

This work is an investigation on slurry erosive wear resistance of stainless steel F6NM used as hydro-turbine material in Dul-Hasti power plant using erodents collected from the same hydro power station dam site located in Kashmir, India. Erodents used in slurry mixture were segregated into three sizes 125, 225 and $325 \mu \mathrm{m}$. The minerals found in erodent were quartz, feldspar, biotite, hornblende and garnet with quartz as the major constituent. The effect of five operating parameters namely (A) sediment concentration (20-30 wt.\%), (B) particle size (125-325 $\mu \mathrm{m}),(C)$ angle of impact (15-45 degree), (D) test duration (450-750 min.) and (E) rotational speed of slurry (500-1000 rpm) on erosive wear of F6NM steel were studied using slurry erosive wear tester (TR-40) at room temperature. The experimental runs were carried out by adopting response surface methodology (RSM) with face centered design for adequate number of runs. It was perceived that three parameters namely rotational speed of slurry, sediment particle size and sediment concentration have major impact on erosive wear. The contribution of rotational speed of slurry, particle size and sediment concentration is $30.58 \%, 18.82 \%$ and $17.64 \%$ respectively for an overall erosion wear. It was observed that increased sediment concentration, higher values of sediment particle size, increasing angle of impact (up to 30 degree only), increased test duration and higher rotational speed of slurry resulted in higher erosive wear material loss. Post mortem studies of the eroded samples (surfaces) were carried out by scanning electron microscopy (SEM) to reveal probable mechanism of material removal. The SEM images of worn surfaces reveal the material is mainly removed owing to formation of abrasive wear tracks, raised lips, crater and grooves due to ploughing and cutting action of erodent particles. Further SEM micrographs of erodent particles (particularly at high speeds and long durations) have been rendered blunt with total or partial removal of sharp edges and thus making them ineffective for further participation on erosive wear process.

(C) 2020 Published by Faculty of Engineering 


\section{INTRODUCTION}

Stainless steels are used in many tribological applications involving erosion including hydroturbine components [1-4]. Different materials have faced severe problems of deterioration due to impact of hard erodents in applications pertaining to slurry erosion [5]. The cast martensitic steel ASTM A743 (CA6NM) is widely used material for the main parts of hydropower plant due to its high strength in combination with good wear resistance [6-8]. Some other grades of steel e.g., $16 \mathrm{Cr} 5 \mathrm{Ni}, \mathrm{CF} 8 \mathrm{M}$ and $18 \mathrm{Cr} 9 \mathrm{Ni}$ are also used [6]. It has been reported that CA6NM steel with large sized sections under slurry erosion conditions presents unsatisfactory performance due to excessive wear $[9,10]$. As a consequence, hydropower industry (where large sized parts are present) has introduced F6NM steel for valves, gates and other hydro-turbine components [11]. The F6NM stainless steel is a potential engineering material for hydro-turbine components to mitigate the effect of erosive wear. Low carbon stainless steel $\mathrm{F} 6 \mathrm{NM}$ is having adequate corrosion resistance, good toughness and weld ability than other grades [12].

The Jammu and Kashmir region in India has approximately hydro power capacity of 20,000 MW and 3263.46 MW only has been exploited so far [13]. Intense wear and tear of hydroelectric turbine machinery is one of the main reasons of the unscheduled shutdown of hydro power plants located in this region of India $[14,15]$. Slurry erosive wear of hydroelectric turbine parts is affected by a host of variables that includes erodent particle size, their shape, velocity, angle of attack and concentration [16]. Moreover, direct effect of composition, microstructure and mechanical properties (of both the surface material and impinging particles) on erosive wear has also been reported [17]. Various components of hydropower plants located in northern India are terribly damaged due to higher silt particle concentration in the river water $[2,18-20]$. The Dul-Hasti power plant located on the Chenab river of Jammu and Kashmir state has been put in the extensive damage category [21]. Besides, during the peak monsoon the Dul-Hasti power plant is usually shutdown when the concentration of solid particles in Chenab River exceeds 2500 ppm [22].
S.R. More et al. investigated the effect of solid particle size, impact velocity, angle of impact and solid concentration on SS 304 using slurry pot test rig [23]. Design of experiments was also reported using Taguchi technique. It was found that particle velocity was more influencing factor than others. Slurry erosive wear was curtailed by maintaining the slurry flow velocity. It was also reported that at different angles of impact the different material mechanisms were observed.

Tahrim Alam et al. studied the effect of velocity and microstructure on slurry erosion of AISI 1018, AISI 1080, API X42 and API X70 steels. It was found that erosion rate increased with increasing slurry velocity and tests were carried out at impact angle of 90 degree [24]. Abhik Mitra et al studied the influence of flow velocity, slurry concentration and duration of testing on slurry erosion of 21CrMoV57 and SS410 metals [25]. The specific mass loss of SS410 was higher as compared to $21 \mathrm{CrMoV} 57$ for an increase in velocity from $4 \mathrm{~m} / \mathrm{s}$ to $16 \mathrm{~m} / \mathrm{s}$. It was observed that with the increase in velocity there was an increase in the formation of pit density with a subsequent decrease in the erosion by platelets mechanism for both the specimen.

In several investigations wear resistance of different grades of martensitic stainless steels under slurry erosion condition have been reported taking into consideration the effect of various operating parameters $[1,6,8,23,26]$. In some studies erodents used included $\mathrm{SiC}$ and $\mathrm{SiO}_{2}$ while erodent size, concentration and other relevant parameters have been chosen in an unorganized way. Cui et al. [27] investigated the erosive wear of F6NM steel with sprayed coating (HVOF) WC-10Co-4Cr at different rotational speeds. In that study it was observed that at velocity $(<6 \mathrm{~m} / \mathrm{s})$, cavitation was the prominent wear mechanism. Under slurry erosion conditions the weight loss for F6NM steel was higher as compared to steel with WC-10Co-4Cr coating. It was further established that at velocity $(>9 \mathrm{~m} / \mathrm{s})$, the impact of abrasive particles lead to more deterioration of $\mathrm{F} 6 \mathrm{NM}$ stainless steel. However WC-10Co-4Cr coated material per formed very well in contrast to uncoated F6NM steel. It is imperative to consider erodents from power station site because many strong particles like quartz, mica, feldspar and garnet are found in such erodents. The hardness values (3-7 on Mohs scale) of 
those erodents is more than the hardness of material being impinged upon [28-31]. The shape and size of erodent particles obtained from the power plant site have also potential influence on the deterioration process involving erosion $[32,33]$.

It is evident from the literature presented that no detailed study is available on the erosive wear of F6NM steel using erodents from power plant site. The use of erodents obtained from power plant site namely Dul-Hasti for determination of erosive wear resistance of F6NM stainless steel (hardness 3-4 on Mohs scale) is a novel idea. In previous studies erodents such as $\mathrm{SiC}, \mathrm{SiO}_{2}$ have been used without any consideration for erodents obtained from a power plant site. Therefore those studies are not providing insights into evaluation of erosion of hydro machinery components located in this region. Moreover, the problem of slurry erosion of hydro-turbines located in northern Himalayan state of Jammu and Kashmir, India has not been reported in literature.

The main objective of present investigation is specifically to assess the erosive wear of hydroturbine material F6NM used at Dul-Hasti power plant. Erodents obtained from the site of Chenab river have been used in a slurry erosive wear tester. It is necessary to find out the erosion pattern of F6NM under various experimental conditions using erodents obtained from power plant site. This will provide insight to examine the cause of extensive wear damage of hydro-turbines. Direct assessment of erosive wear response of F6NM stainless steel will enrich the knowledge related to cause of extraordinary erosion of the turbine components of Dul-Hasti power plant. The surface morphological examinations and eroded surface characterization studies have also been performed and respective wear mechanism has been illustrated.

\section{EXPERIMENTAL DETAILS}

\subsection{Work piece preparation}

The material F6NM stainless steel was procured from authentic source in India. The F6NM stainless steel was in the form of circular bars of diameter $80 \mathrm{~mm}$ and height $150 \mathrm{~mm}$. The rectangular work pieces of $55 \times 15 \times 25 \mathrm{~mm}$ were produced with the help of electric discharge machining. The material composition of F6NM steel is given in Table 1. In advance to experimentation, $\mathrm{SiC}$ sand papers down to 2000 grit were used for work piece polishing. In the end surfaces were mirror polished with $1 \mu$ m slurry of alumina powder on a high speed polishing equipment and finally the work pieces were polished to an average surface roughness $\left(R_{a}\right)$ of $0.07 \mu \mathrm{m}$ (Fig. 1). Further before experimentation the work pieces were thoroughly cleaned with acetone and surfaces were also hot air blown adequately. The work samples were weighed with the help of weighing balance $(0.01 \mathrm{mg}$ least count) and weight of each sample was recorded before and after every experiment.

\subsection{Sediment material}

The sand used in the present study was collected from the Dul-Hasti power house dam site located near Chenab river of Himalayan state of Jammu and Kashmir, India. The sand collected was first dried and then separated using a shaking machine and all the particles larger than $325 \mu \mathrm{m}$ have been removed as their concentration is very low. Sediment size distribution of sand used in the current experimentation is shown in Fig. 2. The sand particle size distribution and its mineral composition were obtained from the petrographic analysis of sediment present in the Chenab River. The percentage of very coarse and fine fractions of sediment for DulHasti power plant is about $2.6 \%$ and $52.2 \%$ respectively [34]. The particle size analysis of sediments present in the Chenab river shows dominance of very fine particle size $(0.085 \mathrm{~mm})$ as a major part. The different minerals present in sand are quartz, biotite, orthoclase-feldspar, calcite, microcline-feldspar, garnet, chloride and iron oxide.

The hardness of majority of these minerals is more than that of hydro-turbine components [29]. The hardness, specific gravity and percentage values of various minerals present in the sand are given in Table 2. The X-ray diffraction examination of the erodents is given in Fig. 3 which gives the chemical composition of sand with silica $\left(\mathrm{SiO}_{2}\right)$ as the leading phase besides silicon phosphate $\left(\mathrm{SiP}_{2} \mathrm{O}_{7}\right)$ and calcium aluminum silicate $\left(\mathrm{CaAl}_{2} \mathrm{Si}_{2} \mathrm{O}_{2}\right)$ as secondary phases. SEM micrograph shows these erodent 
particles are comprised of uneven, zigzag, flat strip shaped particles with sharp and fractured grain margins as given in Fig. 4. To determine the particle shape factor, the SEM photographs of a number of erodent particles were analysed using ImageJ software to obtain the outlines of the particles and measurements of the area and perimeter. The obtained values of erodent particles were then used to calculate the shape factor using the relationship as under [30].

$$
\text { Shape factor, S.F. }=12.56 \mathrm{~A} / \mathrm{P}^{2}
$$

Where $\mathrm{A}$ is the area and $\mathrm{P}$ is the perimeter of the particles projection. More than $50 \%$ of the particles have shape factor between 0.6 and 0.8 which implies that their shapes are angular.

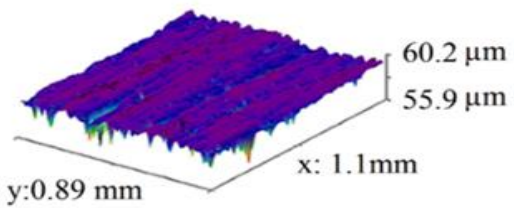

(a)

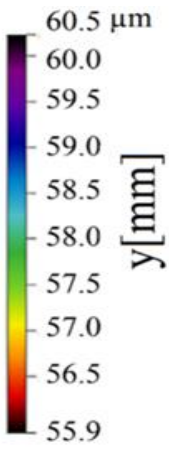

55.9

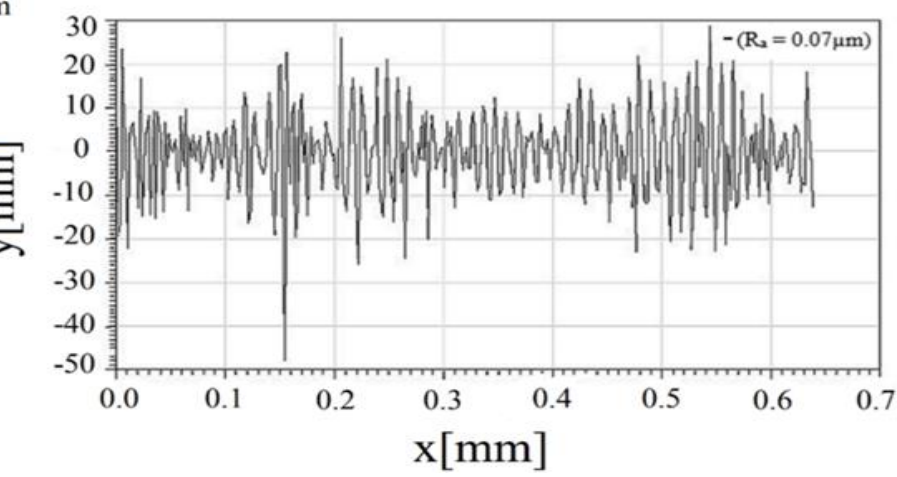

(b)

Fig. 1. (a) 3D surface view of un-eroded F6NM work piece (b) Surface roughness of un-eroded F6NM work piece.

Table 1. Composition of F6NM stainless steel.

\begin{tabular}{|c|c|c|c|c|c|c|c|c|c|c|}
\hline \multirow{2}{*}{ Material } & \multicolumn{10}{|c|}{ Chemical composition [ wt.\%] } \\
\cline { 2 - 13 } & $\mathrm{C}$ & $\mathrm{Si}$ & $\mathrm{Mn}$ & $\mathrm{P}$ & $\mathrm{S}$ & $\mathrm{Cr}$ & $\mathrm{Mo}$ & $\mathrm{Ni}$ & $\mathrm{Ti}$ & $\mathrm{Fe}$ \\
\hline F6NM & 0.037 & 0.580 & 0.630 & 0.020 & 0.012 & 12.89 & 0.507 & 3.730 & 0.017 & 81.02 \\
\hline
\end{tabular}

Table 2. Hardness and percentage of minerals in sand at Dul-Hasti power plant.

\begin{tabular}{|l|c|c|c|c|c|}
\hline Mineral & Quartz & Feldspar & Biotite & Hornblende & Garnet \\
\hline Percentage & $52-55$ & 19 & 10 & 4 & 4 \\
\hline Specific gravity & 2.65 & $2.57-2.76$ & $2.7-3.3$ & $3.05-3.47$ & $3.1-4.3$ \\
\hline Hardness (Mohs) & 7.0 & $6-6.5$ & 5.5 & $2.5-4$ & $5.5-6.5$ \\
\hline
\end{tabular}

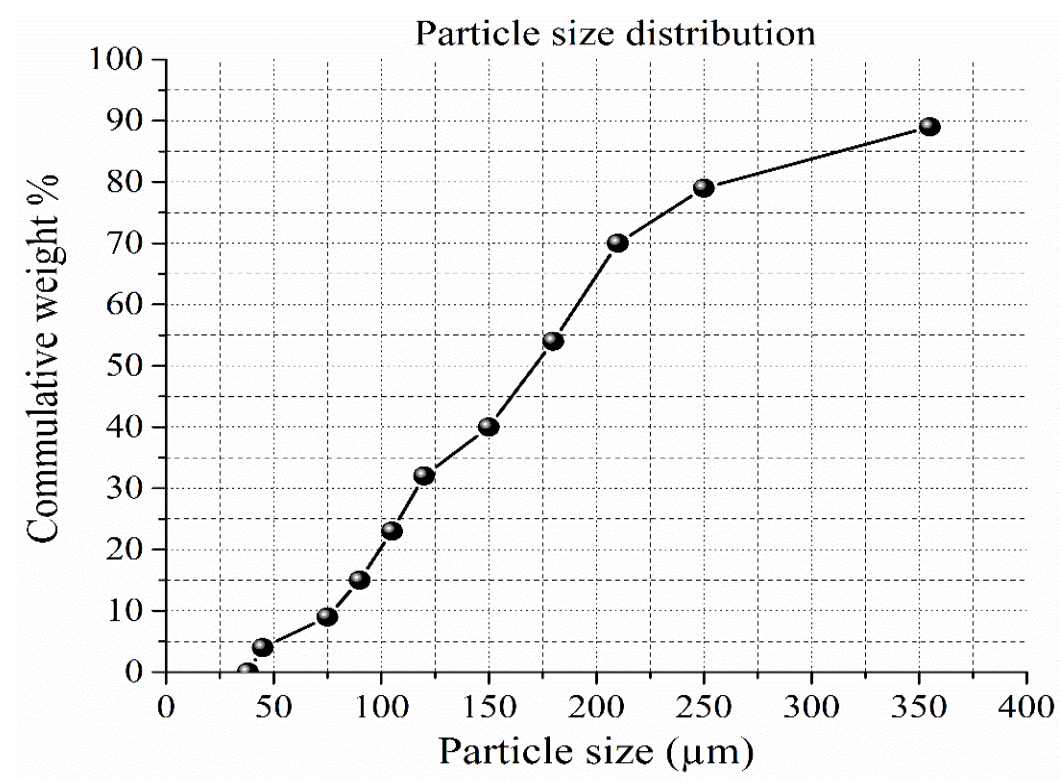

Fig. 2. Sediment size distribution of sand used in the present experimentation. 


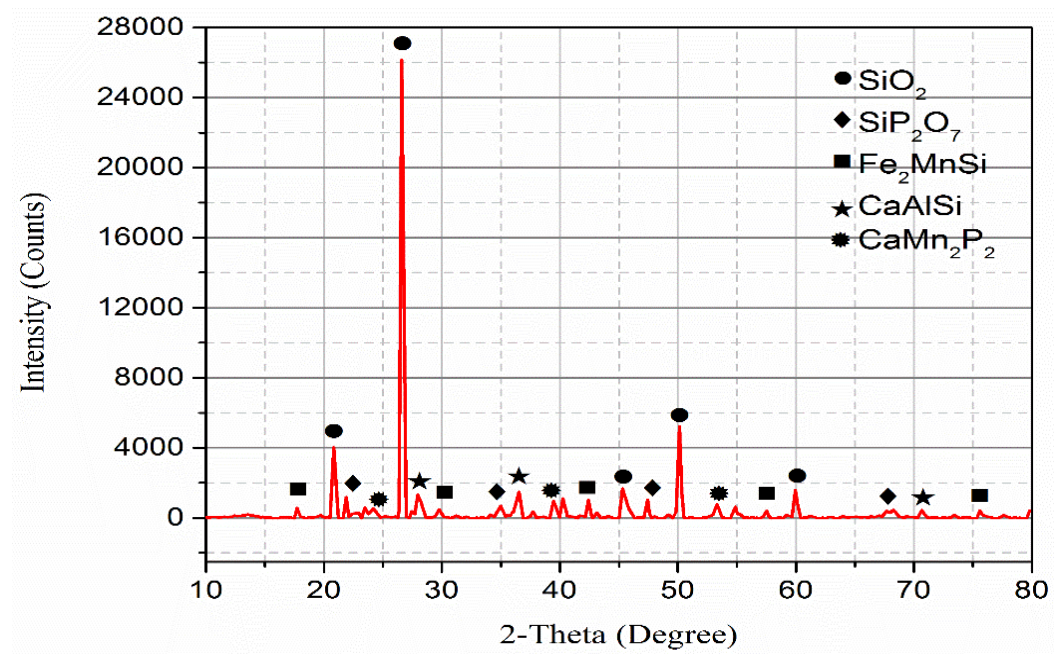

Fig. 3. XRD spectra of erodents obtained from Chenab river site of Dul-Hasti power plant.

Table 3. Levels and codes of operating parameters used in present investigation.

\begin{tabular}{|c|l|c|c|c|c|}
\hline Code & Operating parameters & Units & Level 1 & Level 2 & Level 3 \\
\hline A & Sediment Concentration & $($ Wt. \%) & 20 & 25 & 30 \\
\hline B & Particle Size & $(\mu \mathrm{m})$ & 125 & 225 & 325 \\
\hline C & Angle of impact & $($ degree $)$ & 15 & 30 & 45 \\
\hline D & Test Duration & $(\mathrm{min})$. & 450 & 600 & 750 \\
\hline E & Rotational Speed & $(\mathrm{rpm})$ & 500 & 750 & 1000 \\
\hline
\end{tabular}

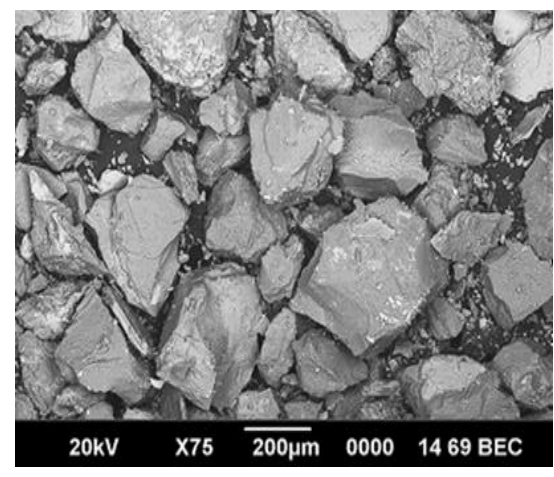

(a) $125 \mu \mathrm{m}$

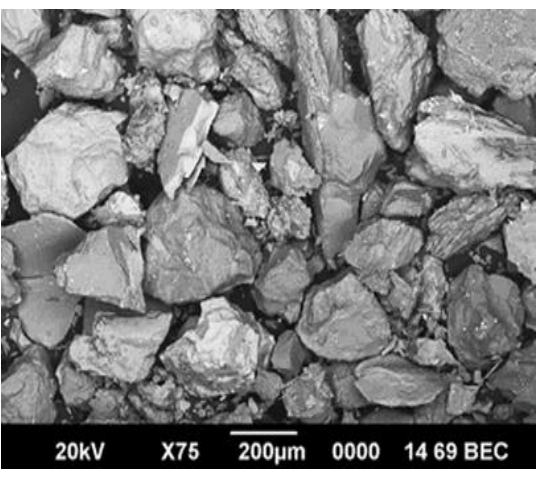

(b) $225 \mu \mathrm{m}$

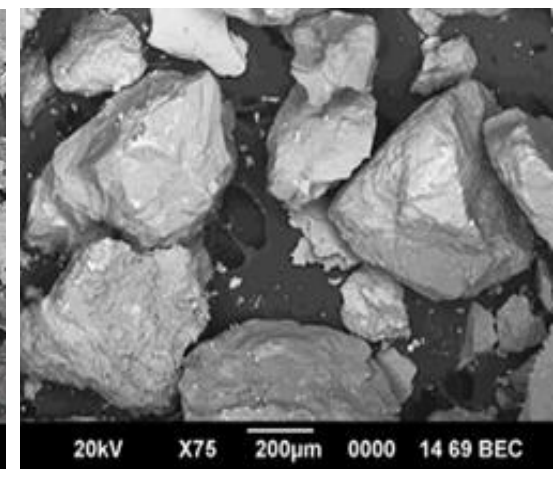

(c) $325 \mu \mathrm{m}$

Fig. 4. SEM images of erodent particles indicating flat strip shapes with sharp and fractured grain margins.

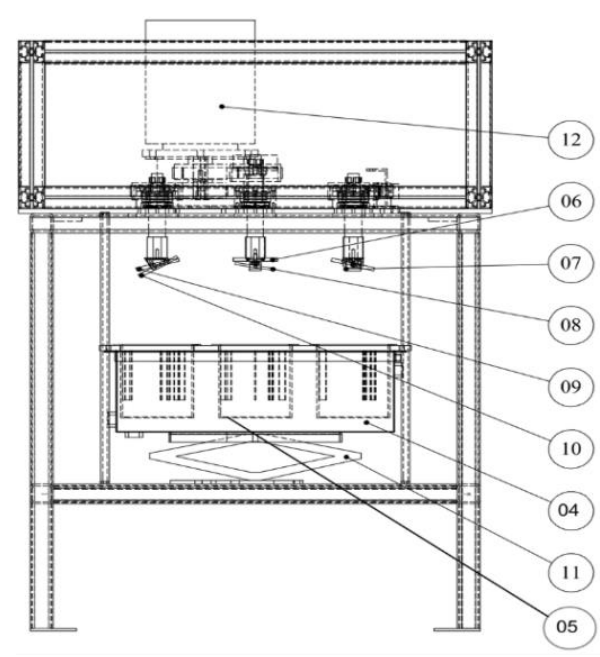

(a) Side View

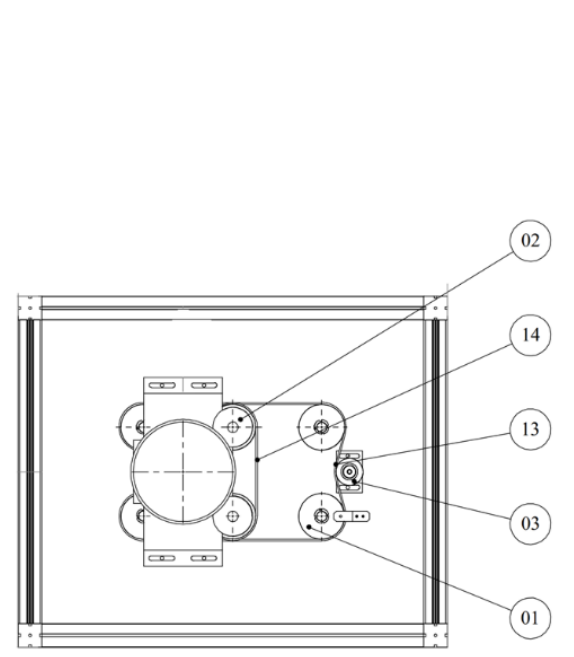

(b) Top View

\begin{tabular}{|l|l|}
\hline S. NO & DESCRIPTION \\
\hline 01 & SPINDLE ASSEMBLY-1 \\
\hline 02 & SPINDLE ASSEMBLY-2 \\
\hline 03 & IDLER PULLEY ASSEMBLY \\
\hline 04 & $\begin{array}{l}\text { COOLANT TANK } \\
\text { ASSEMBLY }\end{array}$ \\
\hline 05 & SLURRY CUPS \\
\hline 06 & SPECIMEN 90 \\
\hline 07 & SPECIMEN 45 \\
\hline 08 & STIRRER \\
\hline 09 & SPECIMEN 15 ${ }^{\circ}$ \\
\hline 10 & SPECIMEN 30 \\
\hline 11 & MOTORIZED JACK \\
\hline 12 & AC MOTOR 1.5KW \\
\hline 13 & $\begin{array}{l}\text { FLAT BELT } \\
\text { 3Tx22Wx1570Lg }\end{array}$ \\
\hline 14 & $\begin{array}{l}\text { FLAT BELT } \\
\text { 3Tx22Wx1570Lg }\end{array}$ \\
\hline
\end{tabular}

Fig. 5. Slurry erosive wear tester used in present investigation with description of various parts. 


\subsection{Test apparatus}

Slurry erosive wear tester ( DUCOM TR40) was used to perform erosion tests. Figures $5 \mathrm{a}$ and $5 \mathrm{~b}$ provides the side and top views of the test rig. It consists of six cylindrical containers having a radius of $60 \mathrm{~mm}$ and height of $150 \mathrm{~mm}$. A motor located at the top of test rig is attached to a spindle that rotates the work piece inside the container. The slurry mixture is kept in suspension by means of baffles attached to the container walls and stirrer plates fastened at the bottom of the test sample by means of screw arrangement. Six samples could be tested simultaneously in this tester.

\subsection{Experimental Methodology}

To examine the effect of the selected parameters namely slurry concentration, sediment particle size, rotational speed, test duration and angle of impact, erosion test runs were carried out using response surface methodology with face centered central composite design for each parameter with three levels. According to this design of experiment 50 experiments only were found to be needed to perform on work samples as compared to 243 experiments if a full factorial design method were selected. The levels and codes of these five operating parameters are given in Table 3.

\section{RESULTS AND DISCUSSION}

The hardness tests were carried on the work samples with digital micro Vickers hardness tester at a load of $10 \mathrm{~N}$ and dwell time $15 \mathrm{~s}$. An average of five hardness test readings are given in Table 4.

Table 4. Hardness of F6NM stainless steel samples.

\begin{tabular}{|c|c|c|c|}
\hline S. No & Hardness & Mean & $\begin{array}{c}\text { Standard } \\
\text { deviation }\end{array}$ \\
\hline 1 & 277 & & \\
\hline 2 & 281 & \multirow{2}{*}{283} & \multirow{2}{*}{3.84} \\
\hline 3 & 283 & & \\
\hline 4 & 286 & & \\
\hline 5 & 288 & & \\
\hline
\end{tabular}

The influence of operating parameters on the erosive wear of F6NM stainless steel is discussed in this section. Weight loss (mg) values were plotted for individual and interaction effects. In this study Pearson $r$ correlation is the statistical tool used to measure the degree of relationship between linearly related variables. The Pearson $r$ correlation is the most widely used correlation statistic tool. Correlation grid is a design tool that presents the preliminary information on the parameter design and also helps to understand the relationships among the variables. The correlations between selected five operating parameters used in this study and response (weight loss) are given in Table 5.

Table 5. Correlation between input parameters and response.

\begin{tabular}{|c|c|c|}
\hline Code & Parameters & $\begin{array}{c}\text { Weight loss } \\
\text { (mg) }\end{array}$ \\
\hline A & Sediment concentration $(w \mathrm{t} . \%)$ & 0.399 \\
\hline B & Particle size $(\mu \mathrm{m})$ & 0.404 \\
\hline C & Angle of impact (degree) & 0.038 \\
\hline D & Test duration $(\mathrm{min})$. & 0.234 \\
\hline E & Rotational speed(rpm) & 0.523 \\
\hline
\end{tabular}

It is evident from Table 5 that rotational speed $(\mathrm{E}=52.3 \%)$ is more correlated to weight loss followed by particle size $(B=40.4 \%)$ and sediment concentration $(A=39.9 \%)$ as compared to angle of impact $(\mathrm{C}=3.8 \%)$ and test duration $(\mathrm{D}=23.4 \%)$. The relationship among five operating parameters and response is given in Table 6.

\subsection{Microstructure}

The microscopic analysis of F6NM steel was carried out on optical microscope with an inbuilt image analysis. It was observed from the Figs. $6 \mathrm{a}$ and $6 \mathrm{~b}$ that the microstructure of the base metal predominantly consists of martensitic matrix with areas of ferrite around the pearlite regions. It was observed from the image analysis that the pearlite content varies between 25 to $30 \%$ and also alternate layered structure of ferrite and pearlite is visible in the micrographs which may be due to the prior mechanical operation like forging. Martensitic areas comprises of plate like structure indicated by white when etched by Nitil. Pearlite areas are dark areas in which alternate plates of ferrite and cementite wear observed. 


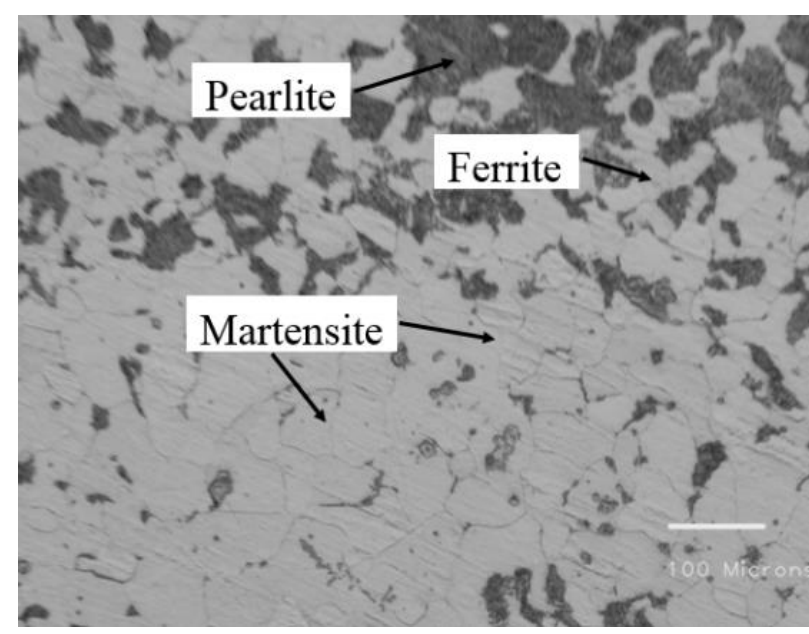

(a)

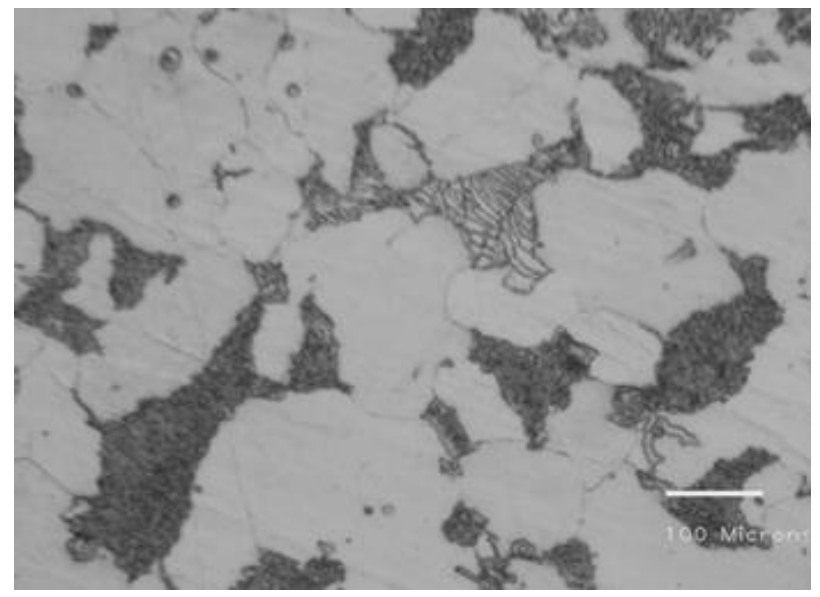

(b)

Fig. 6. Micrographs of F6NM stainless steel.

\subsection{Effect of sediment concentration}

The change in F6NM steel erosive mass loss with an increase in sediment concentration is given in Fig. 7. The increase in the slurry sediment concentration from $20 \mathrm{wt} . \%$ to $30 \mathrm{wt} \% \%$ has been observed to cause higher erosive mass loss. The possibility of increase in number of effective collisions between sediment particles and work piece surface may be due to gain in mass loss with increase in sediment concentration. This escalation in amount of particles hitting against the work piece surface causes an aggravated degradation of material from its surface and to plastic deformation. Similar result trends have been reported by Tian [35], Prasad BK [36] and Clark [16] who suggested that increase in sediment concentration can cause higher surface damage. Further, it can be added that mass loss is amplified due to elevation in a number of interaction among solid particles as a consequence of which particles become sharper and angularity also increases. It is also reported by $[37,38,32]$ that erosive wear rises as angularity increases. Figures $8 \mathrm{a}$ and $8 \mathrm{~b}$ shows the scanning electron micrographs of the degraded surface of F6NM steel work piece after erosive wear testing at lower concentration (20 wt.\%) and at higher concentration (30 wt.\%) respectively. These images reveal that the number of craters discovered on the work-piece eroded at higher sediment concentration is greater as compared to surface eroded at lower concentration and there is also an increase in intensity of small grooves formed on the surface due to abrasive action of erodents. It can be observed from SEM images that erosion mechanism for both the sediment concentration is the formation of craters and grooves due to the ploughing and cutting action of sediment particles on the material surface. Due to formation of craters the material is also displaced from the work piece surface.

\subsection{Effect of sediment particle size}

The influence of sediment particle size on the erosive wear of F6NM steel is shown in Fig. 9. It is noticed that erosive mass loss of F6NM steel increases with the particle size varied from 125 to $325 \mu \mathrm{m}$. At the larger particle size of $325 \mu \mathrm{m}$, maximum mass loss occurs. One of the reasons for this trend is greater abrasive response of larger sized sediment particles on the work piece surface mainly due to bigger mass and larger area of contact between particles and work piece. Rise in mass loss with increase in particle size have been reported by a number of authors [39-43]. Turenne et al. [44] has reported that higher mass loss with enhanced sediment particle size may possibly be due to effect that bigger particles being more effective of directly transferring their energy to the work piece.

Table 6. The relationship among different operating parameters and their response.

\begin{tabular}{|c|c|c|c|c|c|c|}
\hline Run & $\begin{array}{c}\text { (A) } \\
(\mathbf{W t} \mathbf{\%})\end{array}$ & $\begin{array}{c}\text { (B) } \\
(\boldsymbol{\mu} \mathbf{m})\end{array}$ & $\begin{array}{c}\text { (C) } \\
\text { (degree) }\end{array}$ & $\begin{array}{c}\text { (D) } \\
(\mathbf{m i n})\end{array}$ & $\begin{array}{c}\text { (E) } \\
\text { (rpm) }\end{array}$ & $\begin{array}{c}\text { Weight } \\
\text { loss(mg) }\end{array}$ \\
\hline 1 & 20 & 125 & 45 & 750 & 1000 & 0.038 \\
\hline 22 & 20 & 125 & 45 & 750 & 500 & 0.022 \\
\hline
\end{tabular}


I.A. Maekai and G.A. Harmain, Tribology in Industry Vol. 42, No. 2 (2020) 236-254

\begin{tabular}{|c|c|c|c|c|c|c|}
\hline 11 & 20 & 125 & 45 & 450 & 1000 & 0.030 \\
\hline 8 & 20 & 125 & 45 & 450 & 500 & 0.024 \\
\hline 41 & 20 & 125 & 15 & 750 & 1000 & 0.041 \\
\hline 23 & 20 & 125 & 15 & 750 & 500 & 0.019 \\
\hline 48 & 20 & 125 & 15 & 450 & 1000 & 0.025 \\
\hline 30 & 20 & 125 & 15 & 450 & 500 & 0.023 \\
\hline 17 & 20 & 225 & 30 & 600 & 750 & 0.038 \\
\hline 14 & 20 & 325 & 15 & 750 & 1000 & 0.049 \\
\hline 6 & 20 & 325 & 15 & 750 & 500 & 0.025 \\
\hline 2 & 20 & 325 & 15 & 450 & 1000 & 0.028 \\
\hline 15 & 20 & 325 & 15 & 450 & 500 & 0.031 \\
\hline 19 & 20 & 325 & 45 & 750 & 1000 & 0.058 \\
\hline 34 & 20 & 325 & 45 & 750 & 500 & 0.027 \\
\hline 20 & 20 & 325 & 45 & 450 & 1000 & 0.040 \\
\hline 36 & 20 & 325 & 45 & 450 & 500 & 0.038 \\
\hline 5 & 25 & 125 & 30 & 600 & 750 & 0.037 \\
\hline 37 & 25 & 225 & 45 & 600 & 750 & 0.046 \\
\hline 3 & 25 & 225 & 30 & 600 & 750 & 0.036 \\
\hline 13 & 25 & 225 & 30 & 600 & 750 & 0.035 \\
\hline 18 & 25 & 225 & 30 & 600 & 750 & 0.037 \\
\hline 9 & 25 & 225 & 30 & 600 & 750 & 0.036 \\
\hline 39 & 25 & 225 & 30 & 600 & 750 & 0.038 \\
\hline 42 & 25 & 225 & 30 & 600 & 750 & 0.036 \\
\hline 44 & 25 & 225 & 30 & 600 & 750 & 0.040 \\
\hline 49 & 25 & 225 & 30 & 600 & 750 & 0.038 \\
\hline 21 & 25 & 225 & 15 & 600 & 750 & 0.032 \\
\hline 25 & 25 & 225 & 30 & 750 & 750 & 0.047 \\
\hline 26 & 25 & 225 & 30 & 600 & 500 & 0.023 \\
\hline 40 & 25 & 225 & 30 & 450 & 750 & 0.035 \\
\hline 33 & 25 & 225 & 30 & 600 & 1000 & 0.053 \\
\hline 12 & 25 & 325 & 30 & 600 & 750 & 0.047 \\
\hline 10 & 30 & 125 & 15 & 450 & 1000 & 0.029 \\
\hline 29 & 30 & 125 & 15 & 450 & 500 & 0.025 \\
\hline 47 & 30 & 125 & 15 & 750 & 1000 & 0.059 \\
\hline 27 & 30 & 125 & 15 & 750 & 500 & 0.029 \\
\hline 43 & 30 & 125 & 45 & 750 & 1000 & 0.064 \\
\hline 46 & 30 & 125 & 45 & 750 & 500 & 0.030 \\
\hline 38 & 30 & 125 & 45 & 450 & 1000 & 0.026 \\
\hline 31 & 30 & 125 & 45 & 450 & 500 & 0.027 \\
\hline 7 & 30 & 325 & 15 & 750 & 1000 & 0.086 \\
\hline 16 & 30 & 325 & 15 & 450 & 500 & 0.051 \\
\hline 24 & 30 & 325 & 15 & 750 & 500 & 0.036 \\
\hline 50 & 30 & 325 & 15 & 450 & 1000 & 0.062 \\
\hline 28 & 30 & 325 & 45 & 750 & 1000 & 0.069 \\
\hline 32 & 30 & 325 & 45 & 450 & 1000 & 0.053 \\
\hline 35 & 30 & 325 & 45 & 450 & 500 & 0.049 \\
\hline 45 & 30 & 325 & 45 & 750 & 500 & 0.031 \\
\hline
\end{tabular}




\section{Design-Expert $\otimes$ Software}

LOESS Bandwidth: 0.334

Color points by weight loss
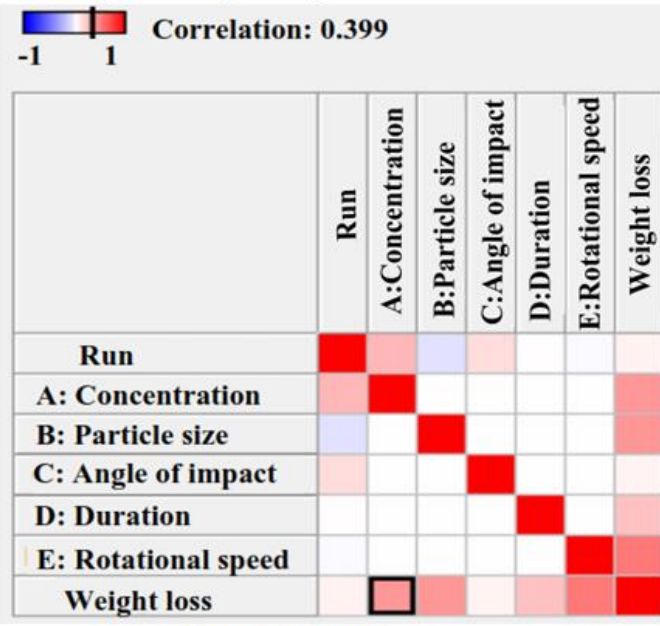

Correlation grid

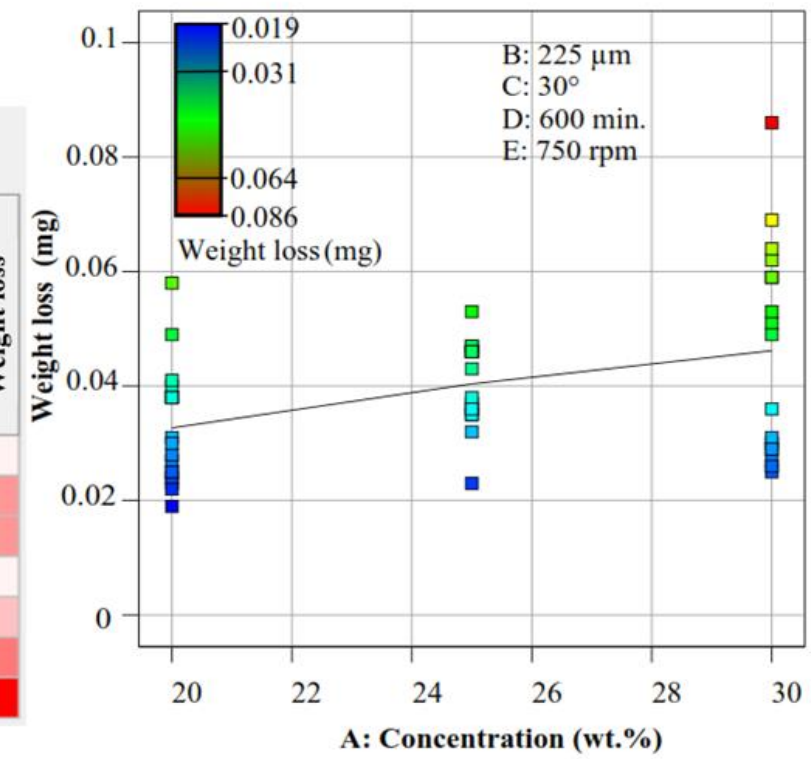

Fig. 7. Variation of weight loss of F6NM steel with different sediment concentration (wt. \%).

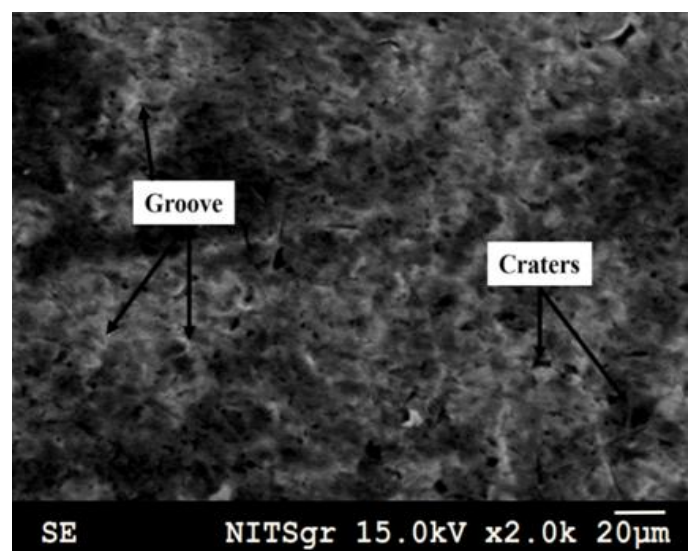

(a)

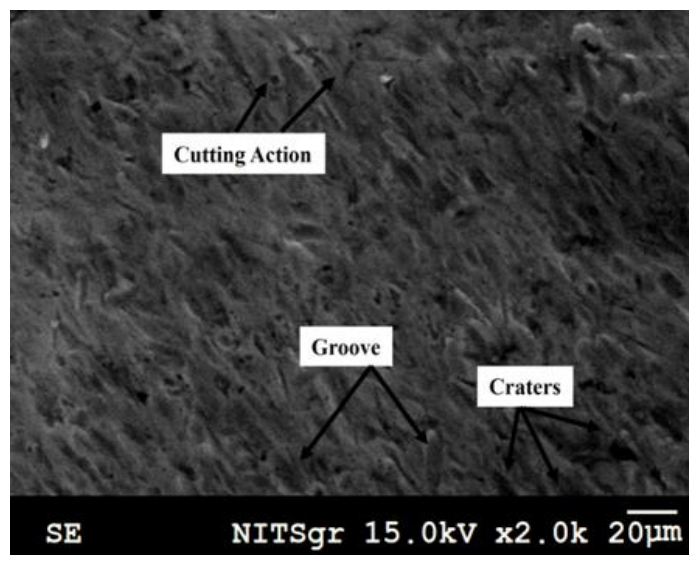

(b)

Fig. 8. SEM micrographs of worn F6NM steel (a) at $A=20 w t . \%, B=225 \mu \mathrm{m}, C=30$ degree, $D=600$ min and $E=750$ rpm and (b) at $A=30$ wt. $\%, B=225 \mu \mathrm{m}, \mathrm{C}=30$ degree, $\mathrm{D}=600 \mathrm{~min}$ and $\mathrm{E}=750 \mathrm{rpm}$.

Design-Expert@ Software

LOESS Bandwidth: 0.334

Color points by weight loss

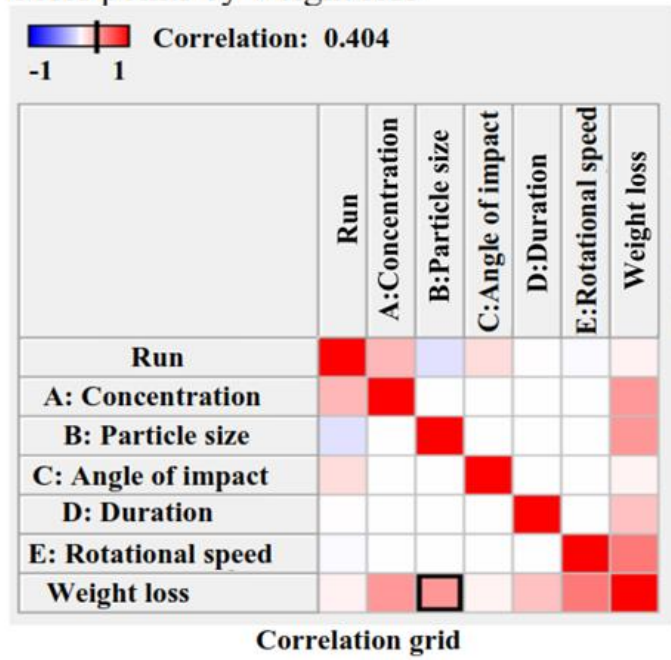

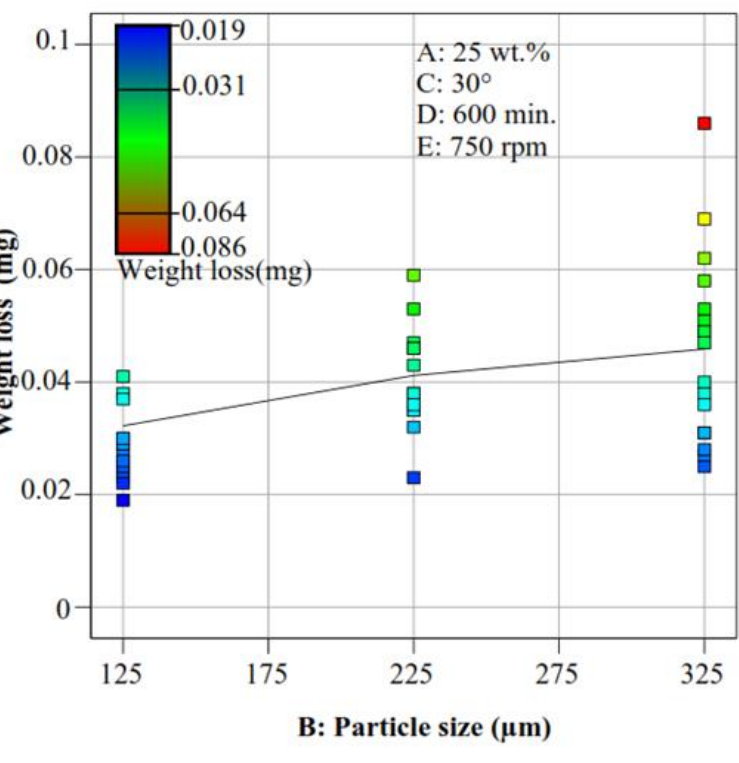

Fig. 9. Variation of weight loss of F6NM steel with different particle size $(\mu \mathrm{m})$. 


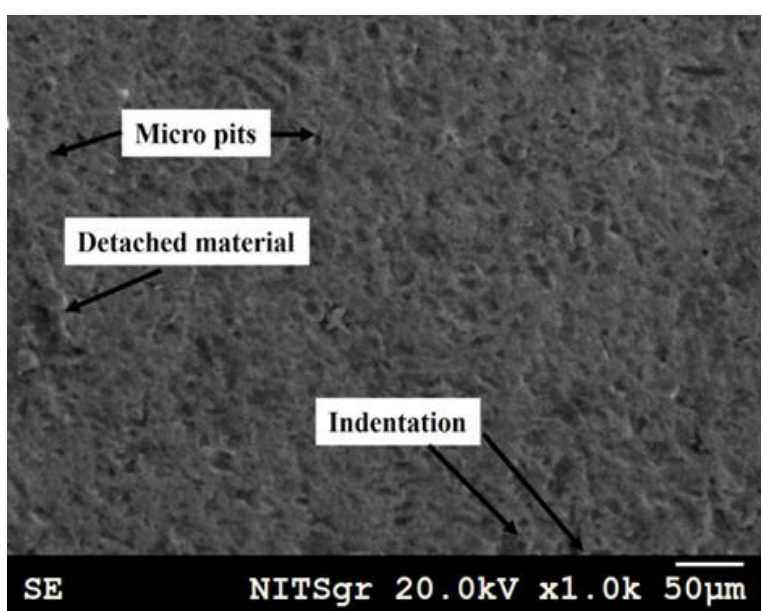

(a)

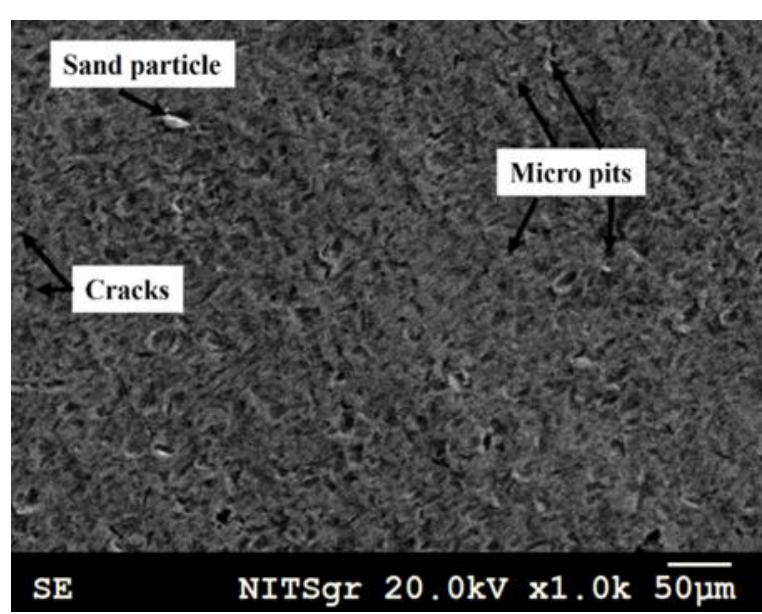

(b)

Fig. 10. SEM images of worn F6NM steel (a) at $A=25 \mathrm{wt} . \%, B=125 \mu \mathrm{m}, \mathrm{C}=30$ degree, $D=600 \mathrm{~min}$ and $E=750 \mathrm{rpm}$ showing less intensity of erosion and (b) at $A=25 \mathrm{wt} \%, \mathrm{~B}=325 \mu \mathrm{m}, \mathrm{C}=30$ degree, $\mathrm{D}=600 \mathrm{~min}$ and $\mathrm{E}=750 \mathrm{rpm}$ with more intensive micro pitting.

\section{Design-Expert@ Software}

LOESS Bandwidth: 0.334

Colorpoints by weight loss

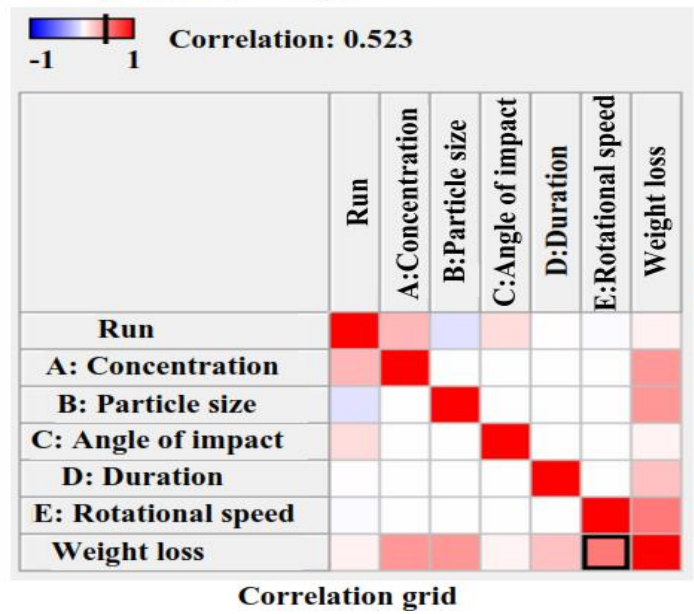

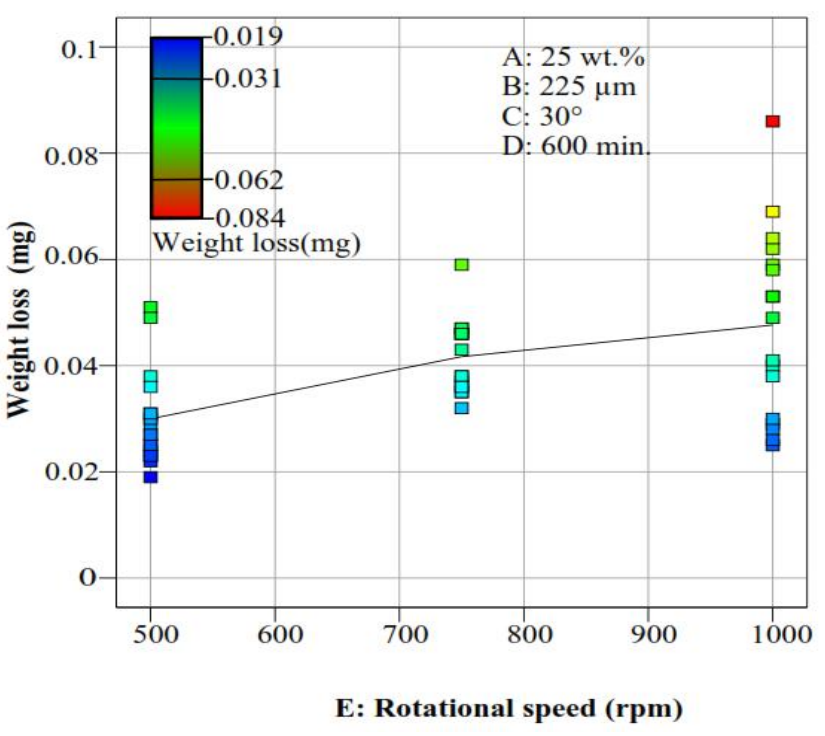

E: Rotational speed (rpm)

Fig. 11. Variation of weight loss of F6NM steel with rotational speed of slurry (rpm).

Further it was noticed that lesser sized particles deviate closer to the surface of work piece and have lower particle energy resulting in decreased mass loss. Moreover when the particle size decreases the number of particles near the material surface are more as compared to large sized particles and as a result of inter-collision among the particles themselves and deviation effect at the surface these small sized particles are not able to wear out the surface properly $[45,46]$.

Lynn et al. [33] also studied the influence of particle size on slurry erosion and it has been reported that small sized sediment particles cannot perfectly start the process of erosion due to lower kinetic energy in contrast to bigger particles and as a consequence of which more material will be detached (by relatively large sized particle) from the material surface therefore mass loss will increase. From the SEM micrographs (Fig. 10) of the eroded surfaces it is apparent that amount of deterioration to material is greater for larger particle size in comparison to smaller size particles. It can be observed from the micrographs that material removal has taken place through micro pit mechanism along with small crack formation. Due to the presence of more number of larger particles at the work piece surface (as already discussed above ) more number of micro pits are formed on the surface and as a result of repeated impacts the higher material eradication occurred in the form of small fragments which are surrounding the micro pits and cracks. 


\subsection{Effect of rotational speed of slurry}

Figure 11 shows the change in weight loss of F6NM steel with distinct rotational speeds of slurry. From this figure it can be perceived that due to increase in rotational speed (500-1000 rpm) the slurry erosion increases. This graph illustrates that maximum weight loss is found at rotational speed of $1000 \mathrm{rpm}$. Chen et al. [47] suggested that mass loss can be associated to fact that impact velocity of erodent particles will be increased with increase in rotational speed of slurry. In turn increased impact velocity will lead to more damage to target surface by removing large volume of material from its surface. Ramesh et al. [48], reported that higher energy is possessed by sand particles at greater rotational speed in contrast to particles at lower speed which will cause more material loss. In order to remove the material adequately from any surface the attacking particles must have critical value of energy.

The abrasive particles not having energy equal or greater than critical energy could not damage the material surface. This could be another feasible justification for low mass loss at lower velocity [49]. H.S Grewal et al. [1] also mentioned in their study that in condition of slurry erosion using the liquid as a carrier fluid the rebounding particles could remain close to the material surface when the velocity of impinging particles is low as compared to the condition of high velocity. In other words, at high velocity the shielding effect of rebounding particles is less effective. Hence at high velocity of striking particles, the erosive mass loss will increase due to reduced shielding effect. In addition to this at higher levels of velocity (of impinging particles) the duration of gap between impacts is decreased leading to higher mass loss as is reported by C. S. Ramesh et al. [39]. Figures $12 \mathrm{a}$ and $12 \mathrm{~b}$ shows the SEM images of the F6NM worn surface at 500 and $1000 \mathrm{rpm}$. It is observed from SEM photographs that eroded work samples at higher rpm (1000) show significantly higher levels of surface erosion which is not evident in contrast to samples at lower rpm (500).

SEM micrographs clearly shows the deep craters are created on the worn surface due to the combined effect of ploughing with micro cutting response of sediment particle resulting in material abrasion in the form of loose flakes. With the increase in rotational speed of slurry the loosened material gets removed at the higher rate in the form of small fragments.

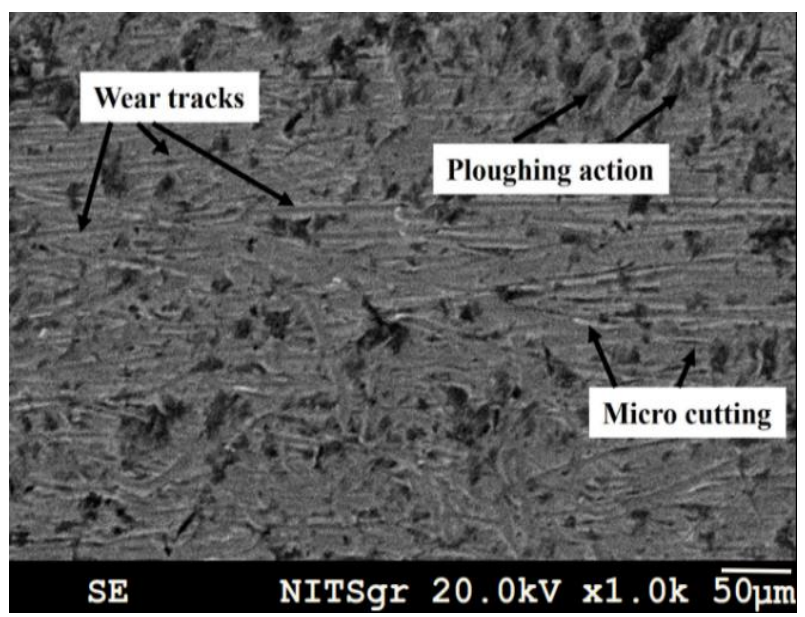

(a)

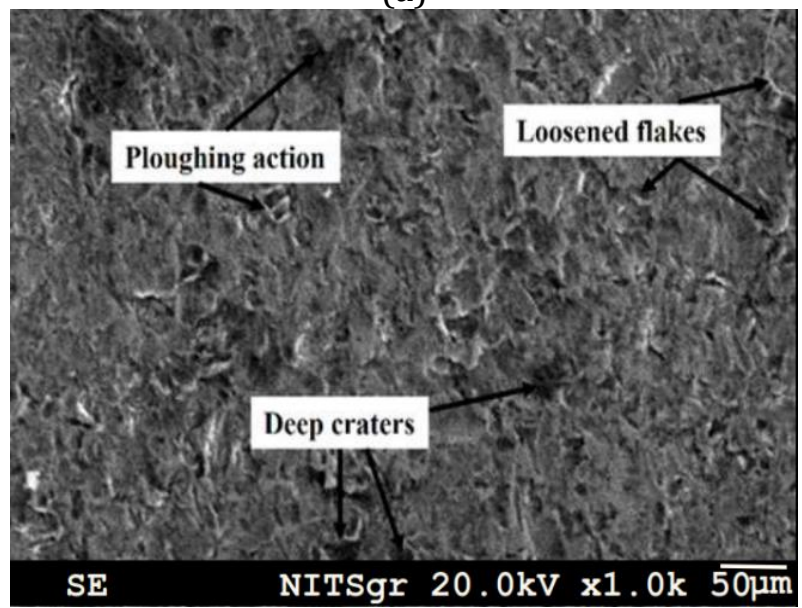

(b)

Fig. 12. SEM images of worn surfaces (a) at $A=25$ wt. $\%, B=225 \mu \mathrm{m}, \mathrm{C}=30$ degree, $\mathrm{D}=600 \mathrm{~min}$ and $\mathrm{E}=500 \mathrm{rpm}$ and (b) at $\mathrm{A}=25 \mathrm{wt} . \%, \mathrm{~B}=225 \mu \mathrm{m}$, $\mathrm{C}=30$ degree, $\mathrm{D}=600 \mathrm{~min}$ and $\mathrm{E}=1000 \mathrm{rpm}$.

\subsection{Effect of test duration on wear loss}

Figure 13 shows the effect of test duration on the slurry weight loss of F6NM steel and it clearly illustrates that weight loss increases with increase in duration of test run (450-750 $\mathrm{min}$ ). Increasing the length of test run increases the number of strikes by impinging particles (frequency) on the target surface which in turn causes more expulsion of material from the surface. Moreover, it is also suggested that higher test time increases the likelihood of particles attacking the destination surface at separate spots hence leading to increased extent of surface damage. In this study the maximum mass loss is observed at test run of $12.5 \mathrm{~h}$ duration, however it is reported in some 
investigations that gain in mass loss due to increase in duration of experiment run is up to certain duration and after that mass loss becomes stable due to aging of slurry, hardening effect and formation of protective oxide layer on the material surface $[50,51,46]$.

The SEM images of sediment particles before the start of test and after the finish of test are shown in Figs. 14a and 14b respectively. It is observed that maximum number of the sand particles have lost their sharpness, angularity and the edges have become soft. Further the maximum number of sand particles are broken into small fragments. The sediment particles are highly defaced and damaged at the end of test run as shown in Fig. 14d as compared to Fig. 14c. Figures $15 \mathrm{a}$ and $15 \mathrm{~b}$ shows the SEM images of the F6NM eroded surface at 450 and $750 \mathrm{~min}$. It can be observed from SEM micrographs that eroded work samples at higher test duration 750 min show deeper groove and pit formation as compared to eroded surface at low test duration due to striking of sediment particles at different spots (as already discussed above). The material is dislodged around the craters formed by plastic deformation and folded raised lips are formed around the crater which in turn (with the passage of time) gets detached from the surface.

\subsection{Effect of angle of impact}

The effect of different angles of impact on mass loss of F6NM steel is shown in Fig. 16. It is found that wear loss increases with increase in angle of impact up to 30 degree and then decreases afterwards. The maximum mass loss is found at around 30 degree angle of impact. The reason for the lower mass loss at 15 degree angle is subsided normal stress and less invasion of target surface by erodent particles, therefore more number of attacks by sediment particles are required to remove the material from the surface. It can be observed from SEM images (Fig. $17 \mathrm{a}$ ) that the lengthy erosive tracks (with lifted lips) are formed on the surface due to reduced normal stress and elevated tangential stress due to sliding and abrasive action of sand particles which is also reported by M. Abedini et al. [52]. However when the impingement angle is increased from (15 degree to 30 degree), the normal stress induced by sand particles also increases which in turn results in formation of erosive wear tracks of shorter length with more lifted lips [53]. The erosive wear tracks of shorter lengths are formed due to less sliding and more invasion of surface by impinging particles [54].

\subsection{Statistical and interaction analysis}

The model for weight loss is given in equation (2). The mathematical model was developed from experimental data obtained from this study using regression approach.

Weight loss $(\mathrm{mg})=0.0397+0.0067 \mathrm{~A}+0.0068 \mathrm{~B}$ $+0.0006 \mathrm{C}+0.0039 \mathrm{D}+0.0088 \mathrm{E}+0.0023 \mathrm{AB}-$ $0.0020 \mathrm{AC}+0.0013 \mathrm{AD}+0.0022 \mathrm{AE}-0.0004 \mathrm{BC}-$ $0.0020 \mathrm{BD}+0.0014 \mathrm{BE}-0.0006 \mathrm{CD}-0.0003 \mathrm{CE}+$ $0.0069 \mathrm{DE}$.

The normal probability plot and comparison plot of actual and predicted weight loss values are given in Figs. 18a and 18b. It is quite evident from these plots that there is no insignificant difference between actual and predicted weight loss values. Figure 19 presents the interaction effects of different operating parameters on erosive weight loss of F6NM steel. It can be observed from Fig. 19a that the interaction between rotational speed and angle of impact ( $\mathrm{E} \times \mathrm{C}$ ) is almost negligible as lines in this figure are parallel to each other. The plots in Figs. $19 \mathrm{~b}$ and $19 \mathrm{c}$ shows the interaction between angle of impact and concentration $(\mathrm{C} \times \mathrm{A})$ and between rotational speed and particle size ( $\mathrm{E} \times \mathrm{B})$ respectively. It is observed that interaction between $\mathrm{E}$ and $\mathrm{B}$ ( E x $B)$ seem to be more significant as compared interaction between $\mathrm{C}$ and $\mathrm{A}(\mathrm{C} \times \mathrm{A})$. For $(\mathrm{E} \times \mathrm{B})$ interaction the effect of increasing particle size is predominant at higher rotational speed than at low speed of slurry. In case of $(\mathrm{C} \times \mathrm{A})$ interaction, the slopes of steady angle lines clearly shows that at $15^{\circ}$ angle of impact and with change in the concentration of slurry from 20 wt.\% to $30 \mathrm{wt} . \%$ has more influence on weight loss. From the Fig. 19(d) it is quite evident that at higher rotational speed the weight loss increases with increment in sediment concentration at higher rate as compared to lower rotational speed. In case of interaction between duration and particle size (D x B). Figure 19e the effect of particle size has predominant effect on the erosive loss at higher test duration. Similarly there is more impact of concentration at large particle size on wear weight loss in comparison to small particle size as shown in Fig. $19 f$. 
Design-Expert $₫$ Software

LOESS Bandwidth: 0.334

Color points by weight loss

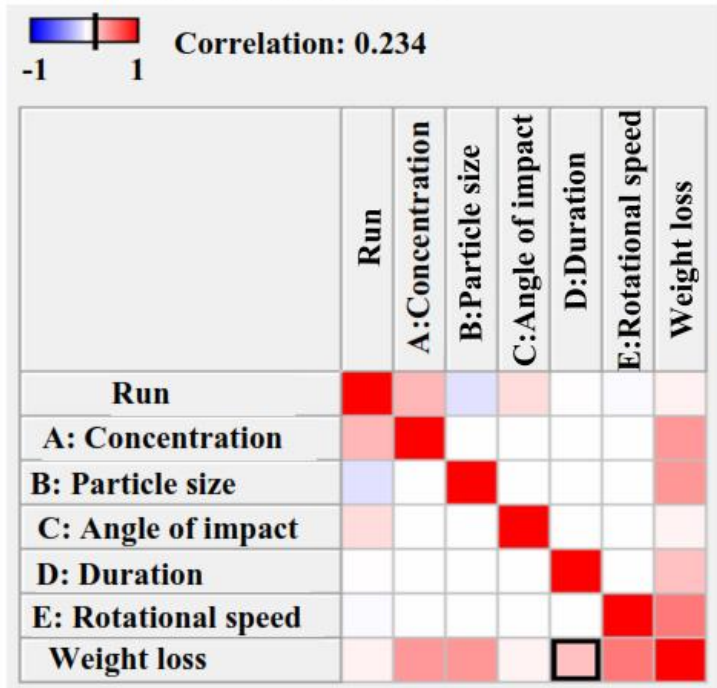

Correlation grid

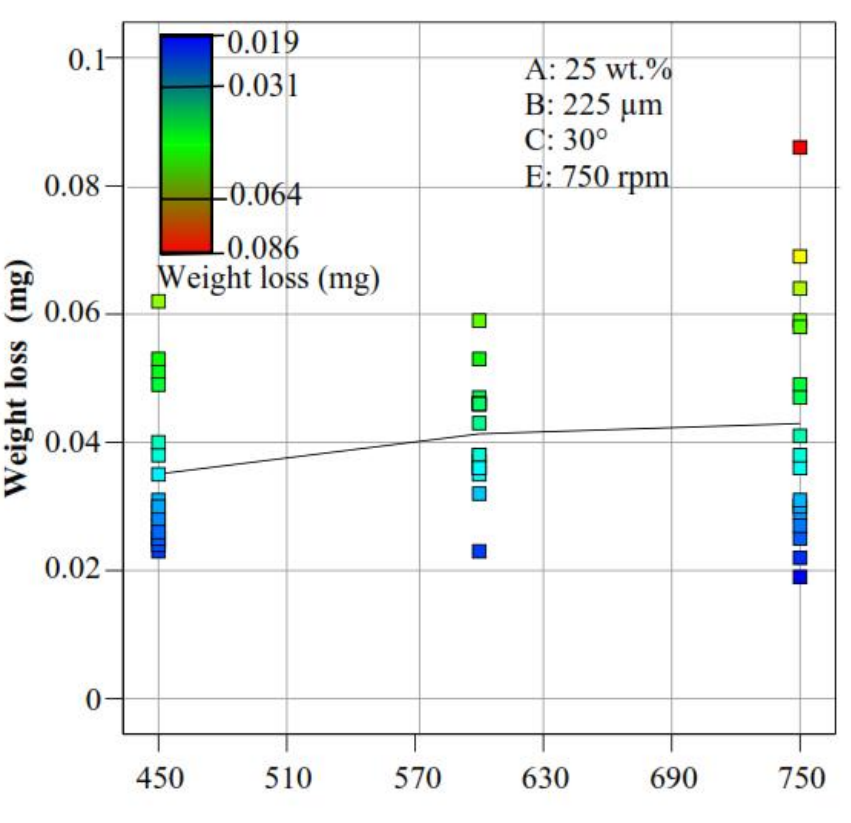

D: Duration (mins.)

Fig. 13. Effect of test duration (min) on weight loss of F6NM steel.

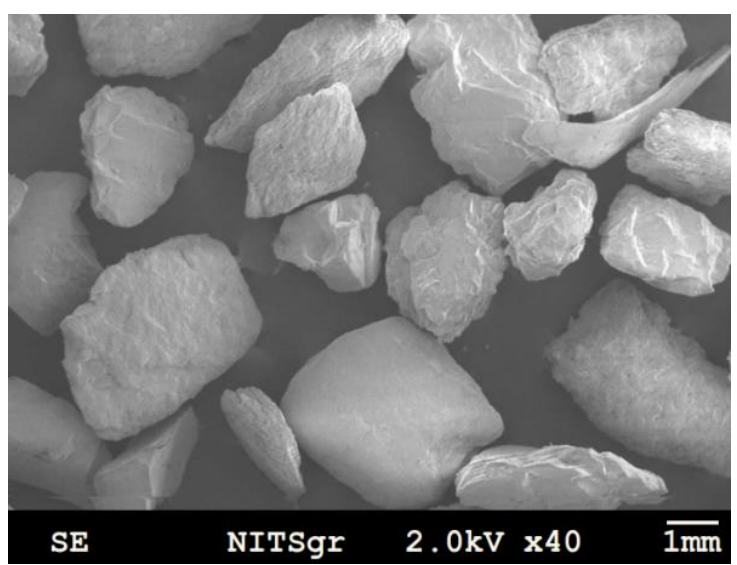

(a) Before experiment

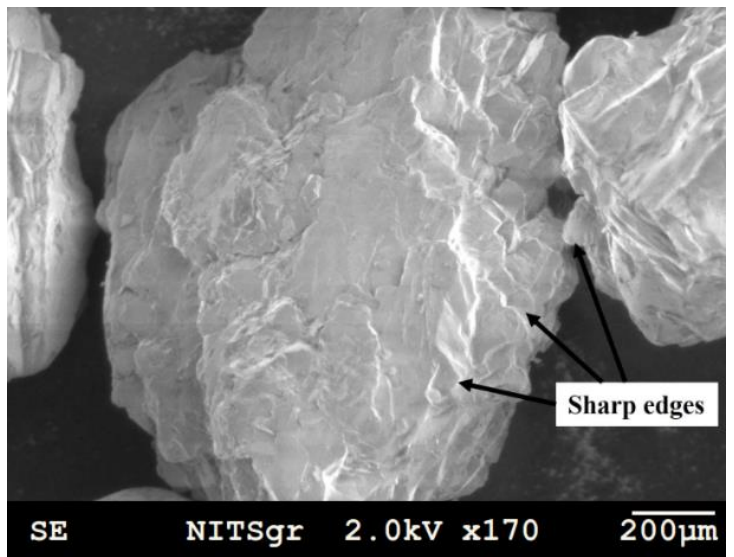

(c) Before experiment

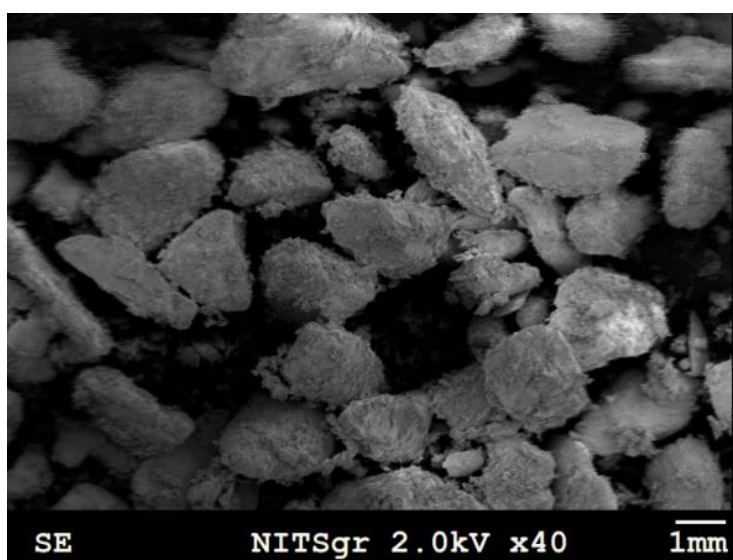

(b) After experiment

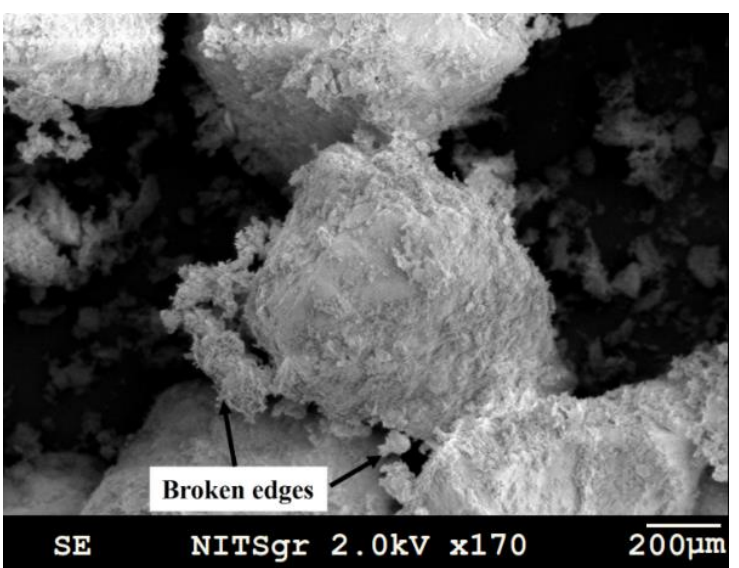

(d) After experiment

Fig. 14. SEM images of sediment particles before and after test run of $750 \mathrm{~min}$. ((a) and (b) respectively) and individual particles ((c) and (d) respectively). 


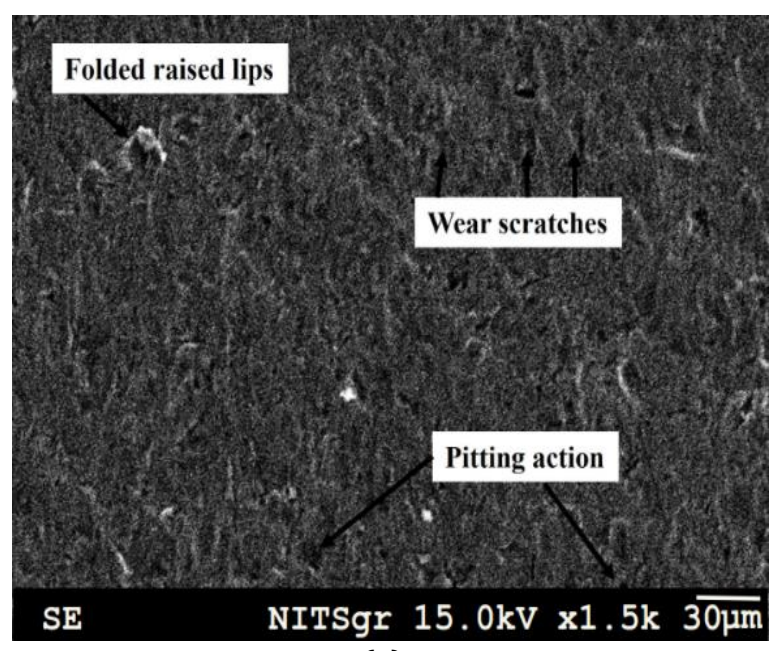

(a)

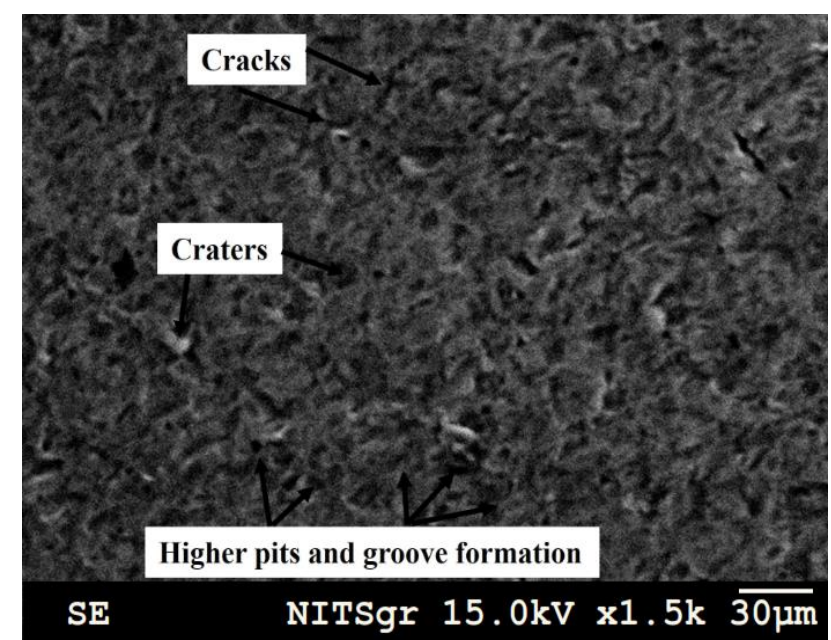

(b)

Fig. 15. SEM images of worn surfaces (a) at $A=25$ wt. $\%, B=225 \mu \mathrm{m}, C=30$ degree, $D=450$ min and $E=750 \mathrm{rpm}$ and (b) at $\mathrm{A}=25 \mathrm{wt} . \%, \mathrm{~B}=225 \mu \mathrm{m}, \mathrm{C}=30$ degree, $\mathrm{D}=750 \mathrm{~min}$ and $\mathrm{E}=750 \mathrm{rpm}$.

Design-Expert $₫$ Software

LOESS Bandwidth: 0.334

Color points by weight loss
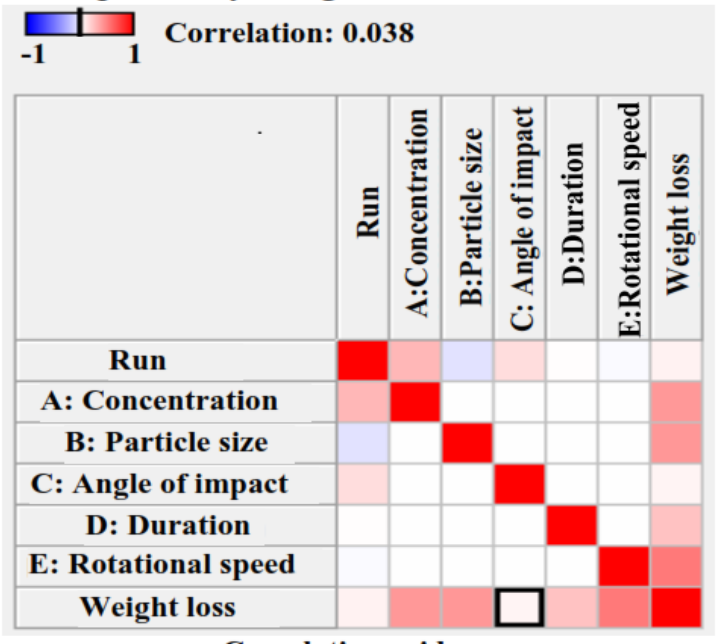

Correlation grid

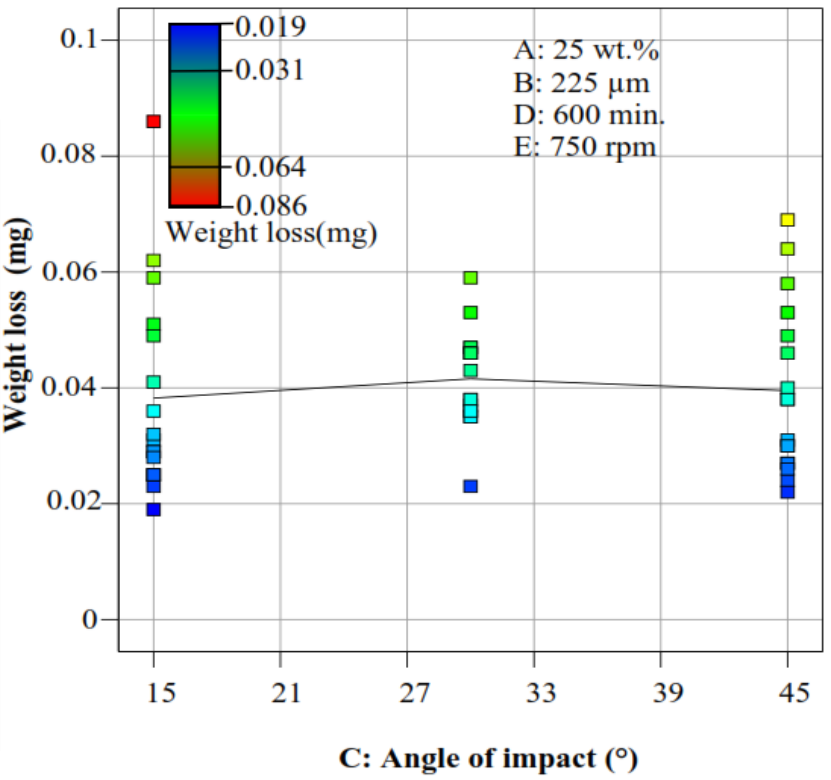

C: Angle of impact $\left({ }^{\circ}\right)$

Fig. 16. Effect of angle of impact (degree) on weight loss of F6NM steel.

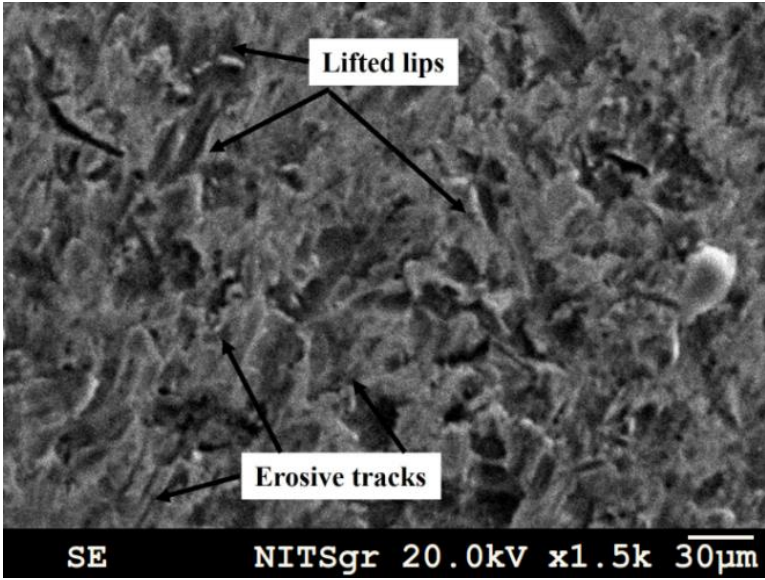

(a)

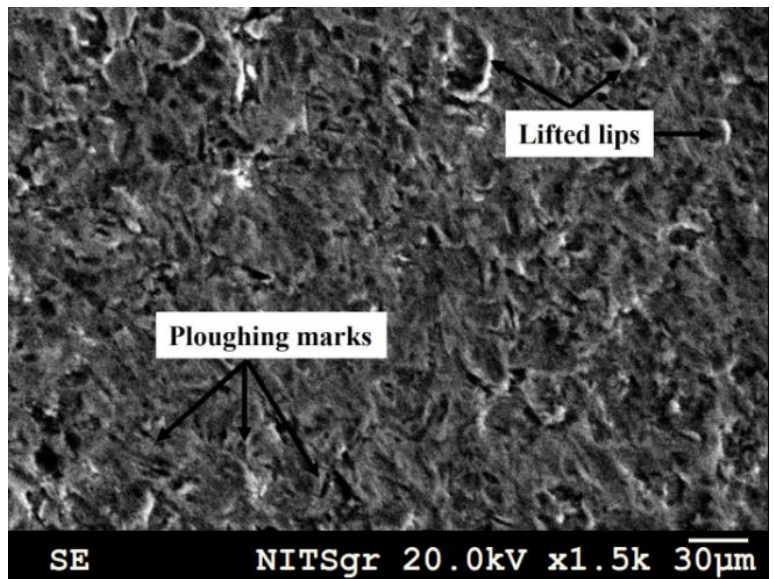

(b)

Fig. 17. SEM images of worn surfaces (a) at $A=25$ wt. $\%, B=225 \mu \mathrm{m}, C=15$ degree, $D=600$ min and $E=750 \mathrm{rpm}$ and (b) at $\mathrm{A}=25 \mathrm{wt} . \%, \mathrm{~B}=225 \mu \mathrm{m}, \mathrm{C}=30$ degree, $\mathrm{D}=600 \mathrm{~min}$ and $\mathrm{E}=750 \mathrm{rpm}$. 


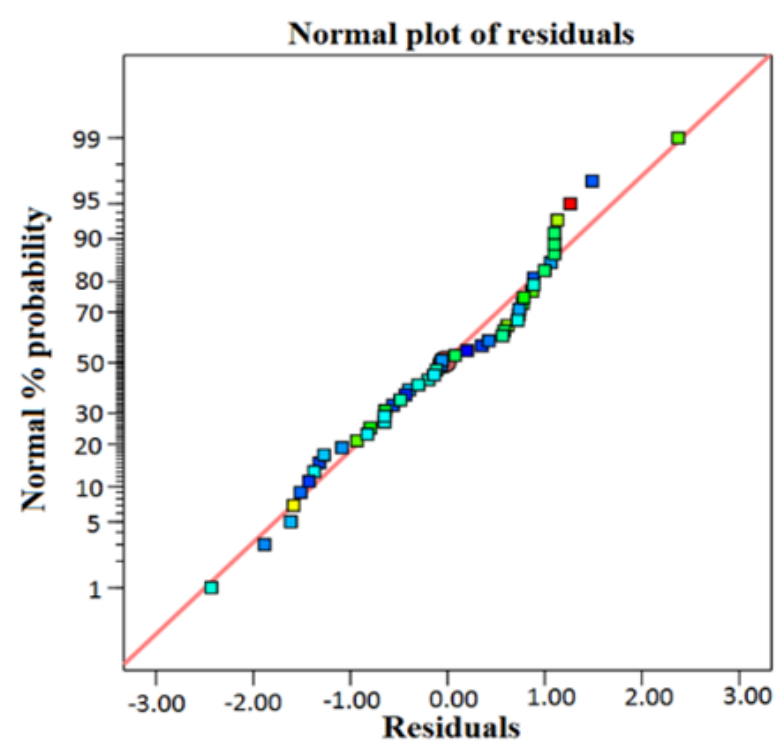

(a)

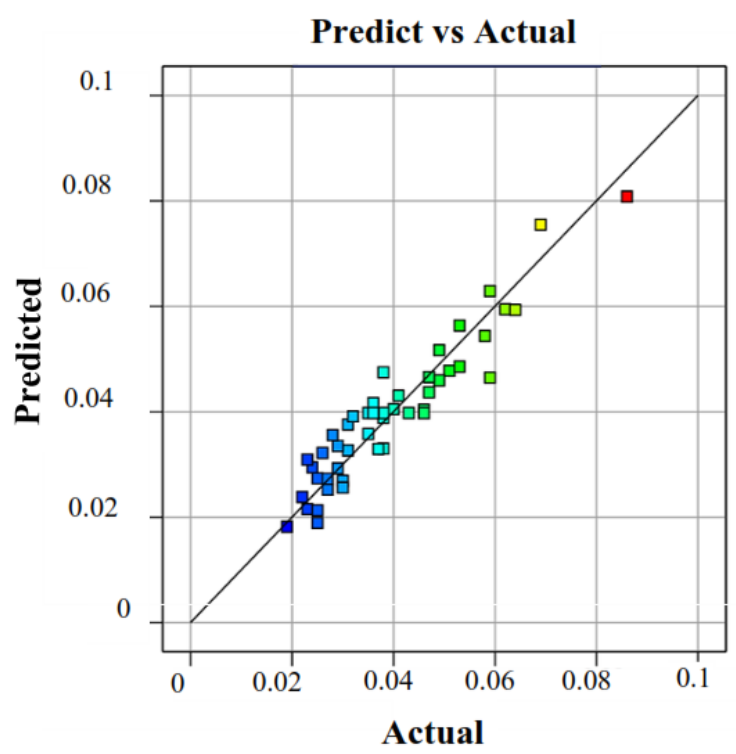

(b)

Fig. 18. (a) Normal probability plot and (b) Predicted vs. Actual plot.

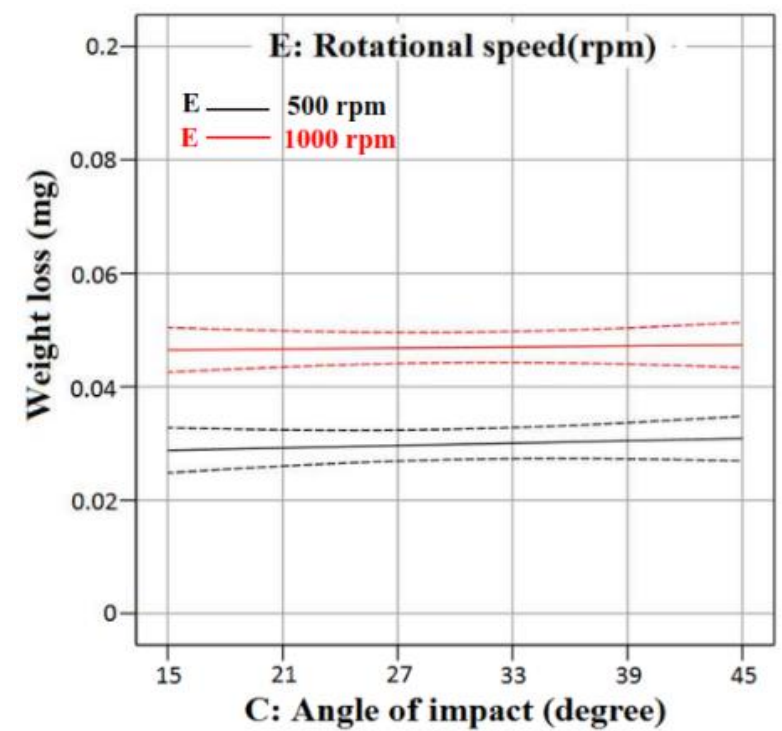

(a)

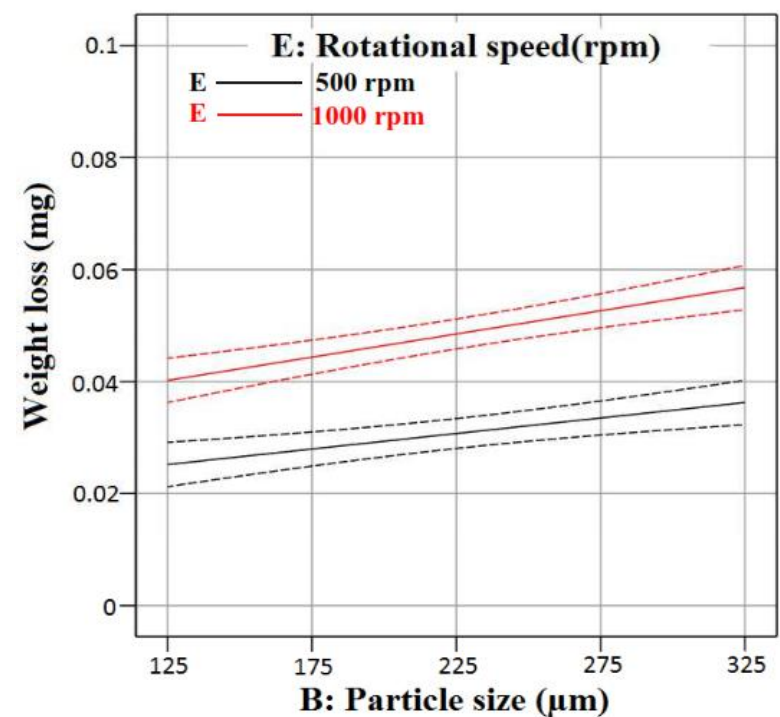

(c)

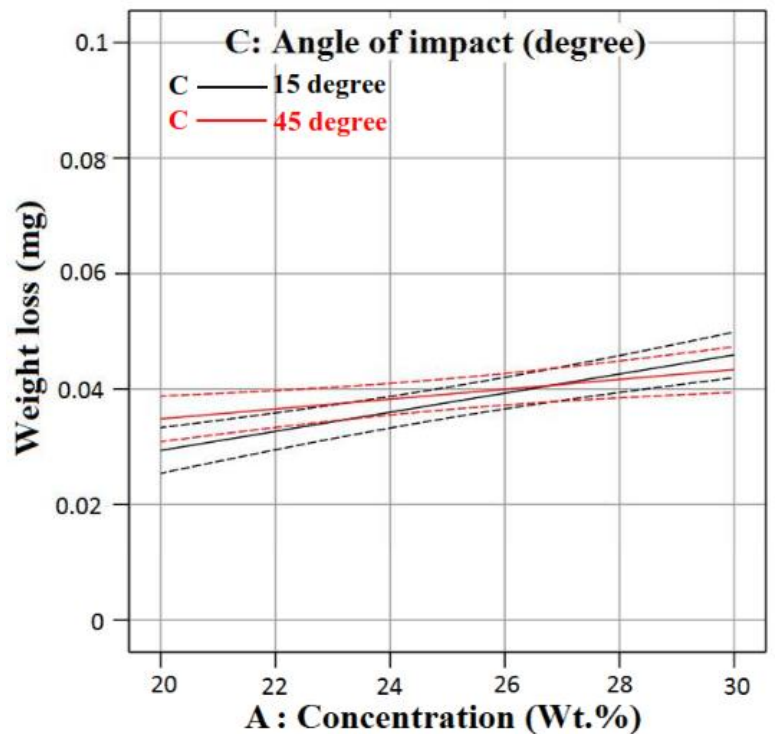

(b)

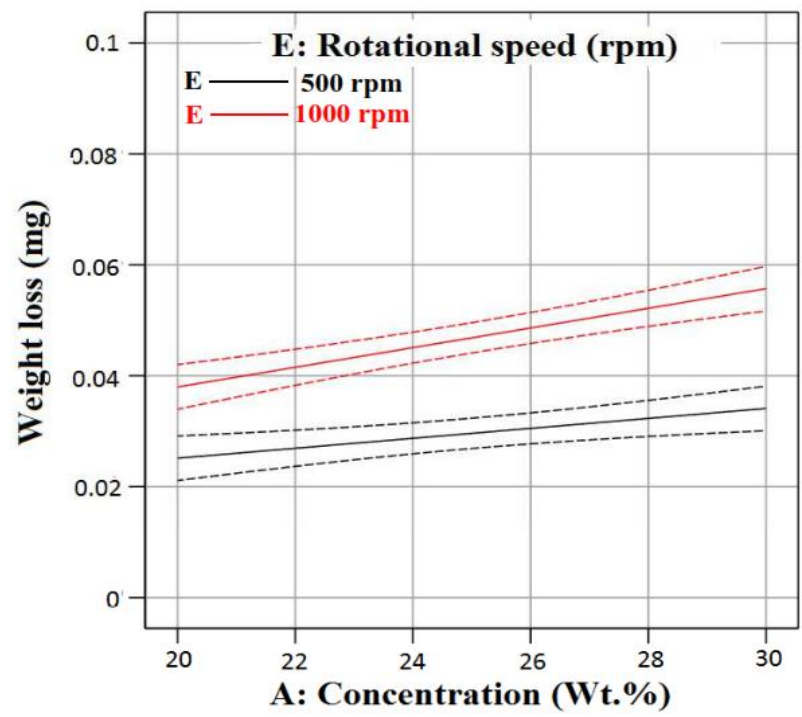

(d) 


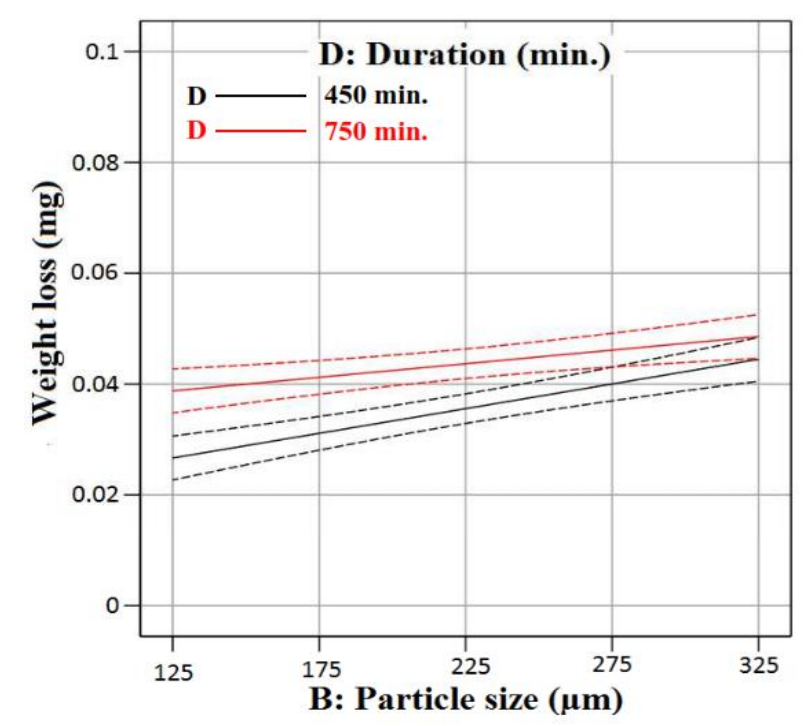

(e)

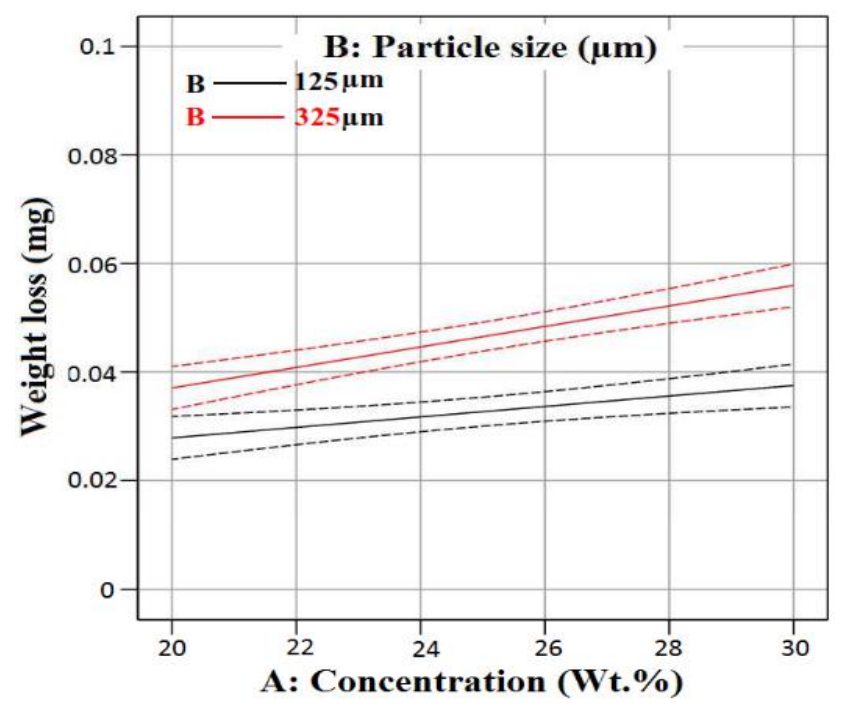

(f)

Fig. 19. shows the effect of interaction between different operating parameters on weight loss of F6NM steel $(a)=$ $(\mathrm{E} \times \mathrm{C}),(\mathrm{b})=(\mathrm{C} \times \mathrm{A}),(\mathrm{c})=(\mathrm{E} \times \mathrm{B}),(\mathrm{c})=(\mathrm{E} \times \mathrm{A}),(\mathrm{e})=(\mathrm{D} \times \mathrm{B})$ and $(\mathrm{f})=(\mathrm{B} \times \mathrm{A})$.

\section{CONCLUSIONS}

In this study, the influence of five main operating parameters on slurry erosion of F6NM steel were studied. The key findings from the current study are:

- The most of sand particles have shape factor between 0.6 and 0.8. XRD examination of sand collected from Dul-Hasti power dam site was conducted in detail. Minerals such as $\mathrm{SiO}_{2}, \mathrm{SiP}_{2} \mathrm{O}_{7}$ and $\mathrm{CaMn}_{2} \mathrm{P}_{2}$ were found to be main constituents.

- Rotational speed of slurry is the most contributing parameter $(30.58 \%)$ on the erosive wear of F6NM steel followed by particle size (18.82 \%) and sediment concentration (17.64\%).

- The experimental results of the current research were used to develop a novel regression based model to forecast erosive weight loss with a maximum deviation (error) of $12 \%$.

- The erosion mechanism was significantly affected by the rotational speed and particle size. At E=1000 rpm deep craters are formed on the worn surface due to the combined effect of ploughing with micro cutting action of sediment particle resulting in material abrasion in the form of loose flakes. At bigger particle size material removal has taken place through micro pit mechanism along with small crack formation.
- SEM studies on F6NM steel eroded surfaces have shown that formation of grooves, cracks, craters and their combination with micro cutting and ploughing are major wear mechanism involved in material removal.

- Pearlitec phase was more prone to erosion in comparison with martensitic phase.

- The material is detached from the work piece by arbitrary and directional attack of sediment particles and owing to sliding and rolling movement of particles on the work piece surface abrasive erosion is caused.

- SEM micrographs of erodent particles (particularly at high speeds and long durations) have been rendered blunt with total or partial removal of sharp edges and thus making them ineffective for further participation on erosive wear process.

\section{REFERENCES}

[1] H.S. Grewal, A. Agrawal, H. Singh, Slurry erosion mechanism of hydro turbine steel: effect of operating parameters, Tribology letters, vol. 52, pp. 287-303, 2014, doi: 10.1007/s11249013-0213-z

[2] A.K. Chauhan, D.B. Goel, S. Prakash, Erosion behavior of hydro turbine steels, Bulletin of Material Science, vol. 31, pp. 115-120, 2008, doi: 10.1007/s12034-008-0020-6

[3] J.F. Santa, J.C. Baena, A. Toro, Slurry erosion of thermal spray coatings and stainless steels for 
hydraulic machinery, Wear, vol. 263, iss.. 1-6, pp. 258-264, 2007, doi: 10.1016/j.wear.2006.12.061

[4] S. Kumar, J.S. Ratol, Effects of tribological parameters on slurry erosion behaviour uncoated and coated materials: a review, Materials Engineering, vol. 20, iss. 3, pp. 119-131, 2013.

[5] X. Yongsong, J.J. Jiang, K.Y. Tufa, S. Yick, Wear resistance of materials used for slurry transport, Wear, vol. 332-333, pp. 1104-1110, 2015, doi: 10.1016/j.wear.2015.01.005

[6] Y. Iwabuchi, S. Sawada, Metallurgical characteristics of a large hydraulic runner casting of type $13 \mathrm{Cr}-\mathrm{Ni}$ stainless steel, ASTM International, pp. 332-354, 1982, doi: 10.1520/STP28449S

[7] H.S. Arora, H.S. Grewal, H. Singh, S. Mukherjee, Zirconium based bulk metallic glass- Better resistance to slurry erosion compared to hydro turbine steel, Wear, vol. 307, iss. 1-2, pp. 28-34, 2013, doi: 10.1016/j.wear.2013.08.016

[8] J.F. Santa, L.A. Espitia, J.A. Blanco, S.A. Romo, A. Toro, Slurry and cavitation erosion resistance of thermal spray coatings, Wear, vol. 267, iss. 1-4, pp. 160-167,2009, doi: 10.1016/j.wear.2009.01.018

[9] B. S. Mann, Boronizing of cast martensitic chromium nickel stainless steel and its abrasion and cavitation erosion behavior, Wear, vol. 208, iss. 1-2, pp. 125-131, 1997, doi: 10.1016/S0043-1648(96)07374-7

[10] R. Chattopadhyay, High silt wear of hydro turbine runners, Wear, vol. 162-164, pp. 1040-1044, 1993, doi: 10.1016/00431648(93)90119-7

[11] J. Svoboda, Literature Review of Martensitic Stainless steels, Steel Founders Society of America, 1982.

[12] A. Raymond, B. Higgins, Properties of Engineering Materials, Hodder and Stoughton, London, 1985.

[13] M. Ahmad, Development of Hydropower Projects in Jammu and Kashmir, International Journal of Trend in Research and Development, vol. 6, no. 1, pp. 6-8, 2019.

[14] H. Grein, Schachenmann, A Solving problems of abrasion in hydroelectric machinery, Water Power and Dam Construction, vol. 8, pp. 19-24, 1992.

[15] S. Chitrakar, H.P. Neopane, O.G. Dahlhaug, Study of the simultaneous effects of secondary flow and sediment erosion in Francis turbines, Renewable Energy, vol. 97, pp. 881-889, 2016, doi: 10.1016/j.renene.2016.06.007

[16] H. Mcl Clark, R.J. Llewellyn, Assessment of the erosion resistance of steels used for slurry handling and transparent in mineral processing application, Wear, vol. 250, iss. $1-12$, pp. 32-44, 2001, doi: 10.1016/S0043-1648(01)00628-7

[17] C.G. Duan, V.Y. Karelin, Abrasive erosion and corrosion of hydraulic machinery, Imperial College Press, London, pp. 4- 34, 2004.

[18] D.K. Goyal, H. Singh, H. Kumar, V. Sahni, Slurry erosion behavior of HVOF sprayed WC-10Co-4Cr and $\mathrm{Al}_{2} \mathrm{O}_{3}+13 \mathrm{TiO}_{2}$ coatings on a turbine steel, Wear, vol. 289, pp. 46-57, 2012, doi: 10.1016/j.wear.2012.04.016

[19] G.F Truscott, A literature survey on abrasive wear in hydraulic machinery, Wear, vol. 20, iss. 1, pp. 2950, 1972, doi: 10.1016/0043-1648(72)90285-2

[20] H. Neopane, O. Dahlhuag, M. Cervantes, Sediment erosion in hydraulic turbines, Global Journal Engineering, vol. 11, no. 6, pp. 16-26, 2011.

[21] B. Naidu, Developing silt consciousness in the minds of hydropower engineers, Proceedings of Ist international conference on silting problems in hydropower plants, CRC Press, London, 1999.

[22] J.H Masoodi, G.A. Harmain, Sediment erosion of francis turbine runners in the Himalayan region of India, Hydropower and Dams, vol. 24, iss. 1, pp. 82-89, 2017.

[23] S.R. More, D.V. Bhatt, J.V. Menghani, Study of the parametric performance of solid particle erosion wear under slurry pot test rig, Tribology in Industry, vol. 39, no.4, pp. 471-481, 2017.

[24] T. Alam, Md.A. Islam, Z.N. Farhat, Slurry Erosion of Pipeline Steel: Effect of Velocity and Microstructure, Journal of Tribology, vol. 138, iss. 2, p. 10, 2016, doi: 10.1115/1.4031599

[25] A. Mitra, A. Shukla, A. Kumar, Amit, A. Kumar, R. Mittal, Analysis of Performance of X21CrMoV57 and SS 410 under Simulated Conditions of Pelton Turbine with the help of Slurry Erosion Test Rig, Materials today proceedings, vol. 5, iss. 9, pp. 18839-18847, 2018, doi: 10.1016/j.matpr.2018.06.231

[26] S. Bhandari, H. Singh, H.K. Kansal, V. Rastogi, Slurry erosion studies of hydroturbine steels under hydro accelerated conditions, Proceedings of the Institution of Mechanical Engineers, Part J: Journal of Engineering Tribology, vol. 226, iss. 3, pp. 239-250, 2011, doi: $10.1177 / 1350650111428238$

[27] S.Y. Cui, Q. Miao, W.P. Liang, B.Z. Huang, Z. Ding, B.W. Chen, Slurry Erosion Behavior of F6NM Stainless Steel and High-Velocity Oxygen Fuel-Sprayed WC-10Co-4Cr Coating, Journal Thermal Spray Technology, vol. 26, pp. 473482, 2017, doi: 10.1007/s11666-016-0515-4 
[28] Y.I. Oka, K. Okamura, T. Yoshida, Practical estimation of erosion damage caused by solid particle impact Part 1: Effects of impact parameters on a predictive equation, Wear, vol. 259, iss. 1-6, pp. 95-101, 2005, doi: 10.1016/j.wear.2005.01.039

[29] J.H. Masoodi, G.A. Harmain, A methodology for assessment of erosive wear on a Francis turbine runner, Energy, vol. 118, pp. 644-657, 2016. doi: 10.1016/j.energy.2016.10.095

[30] G.R. Desale, B.K. Gandhi, S.C. Jain, Effect of erodent properties on erosion wear of ductile type materials, Wear, vol. 261, iss. 7-8, pp. 914921, 2006, doi: 10.1016/j.wear.2006.01.035

[31] B.S. Thapa, B. Thapa, O.G. Dahlhaug, Empirical modelling of sediment erosion in Francis turbines, Energy, vol. 41, iss. 1, pp. 386-391, 2012, doi: 10.1016/j.energy.2012.02.066

[32] S. Bahadur, R. Badruddin, Erodent particle characterization and the effect of particle size and shape on erosion, Wear, vol. 138, iss. 1-2, pp. 189-208, 1990, doi: 10.1016/00431648(90)90176-B

[33] R.S. Lynn, K.K. Wong, H.Mcl. Clark, On the particle size effect in slurry erosion, Wear, vol. 149, iss. 1-2, pp. 55-71, 1991, doi: 10.1016/0043-1648(91)90364-Z

[34] National Council for Cement and Building Materials 2012 Petrographic study of silt sediments of Chenab river at Keru and Kwar Report CRT-OM-SP2751 Haryana.

[35] H.H. Tian, G.R. Addie, Experimental study on erosive wear of some metallic materials using corrollis wear testing approach, Wear, vol. 258, iss. 1-4, pp. 458-469, 2005, doi: 10.1016/j.wear.2004.09.002

[36] B.K. Prasad, O.P. Modi, A.H. Yegneswaran, Wear behavior of zinc-based alloys as influenced by alloy composition nature of slurry and traversed distance, Wear, vol. 264, iss. 11-12, pp. 9901001, 2008, doi: 10.1016/j.wear.2007.08.003

[37] A.V. Levy, Solid particle erosion and erosioncorrosion of materials, ASM International, Materials Park, Ohio, 1995.

[38] A.V. Levy, G. Hickey, Liquid-solid particle slurry erosion of steels, Wear, vol. 117, iss. 2, pp. 129146, 1987, doi: 10.1016/0043-1648(87)90251-1

[39] C.S. Ramesh, R. Keshavamurthy, B.H. Channabasappa, S. Pramod, Materials and Design, vol. 30, iss. 9, pp. 3713-3722, 2009, doi: 10.1016/j.matdes.2009.02.009

[40] I.M. Hutchings, R.E. Winter, Particle erosion of ductile metals: a mechanism of material removal, Wear, vol. 27, iss. 1, pp. 121-128, 1974, doi: 10.1016/0043-1648(74)90091-X

[41] G. Sundrarajan, P.G. Shewmon, A new model for the erosion of metals at normal incidence, Wear, vol. 84, iss. 2, pp. 237-258, 1983, doi: 10.1016/0043-1648(83)90266-1

[42] R.J.K. Wood, T.F. Jones, J. Ganeshalingam, N.J. Miles, Comparison of predicted and experimental erosion estimates in slurry ducts, Wear, vol. 256, iss. 9-10, pp. 937-947, 2004, doi: 10.1016/j.wear.2003.09.002

[43] Y.I. Oka, H. Ohnogi, T. Hosokawa, M. Matsumura, The impact angle dependence of erosion damage caused by solid particle impact, Wear, vol. 203-204, pp. 573-579, 1997, doi: 10.1016/S0043-1648(96)07430-3

[44] S. Turenne, M. Fiset, J. Masounave, The effect of sand concentration on the erosion of materials by a slurry jet, Wear, vol. 133, iss. 1, pp. 95-106, 1989, doi: 10.1016/0043-1648(89)90116-6

[45] R.G. Desale, B.K. Gandhi, S.C. Jain, Particles size effect on slurry erosion of aluminum alloy (AA6063), Wear, vol. 266, iss. 11-12, pp. 106671, 2009, doi: 10.1016/j.wear.2009.01.002

[46] S. Turenne, Y. Chatigny, D. Simard, S. Caron, J. Masounave, The effect of abrasive particle size on slurry erosive wear resistance of particulate reinforced aluminum alloy, Wear, vol. 141, iss. 1, pp. 147-58, 1990, doi: 10.1016/00431648(90)90199-K

[47] J.W. Liou, T.S. Liu, L.H. Chen, SiO2 particle erosion of A356 aluminum alloy and the related microstructural changes, Wear, vol. 211, iss. 2, pp. 169-76, 1997, doi: 10.1016/S00431648(97)00105-1

[48] C.S. Ramesh, R. Keshavamurthy, Slurry erosive wear behavior of $\mathrm{Ni}-\mathrm{P}$ coated Si3N4 reinforced Al6061 composites, Materials \& Design, vol. 32, iss. 4, pp. 1833-1843, 2011, doi: 10.1016/j.matdes.2010.12.024

[49] H. Mcl. Clark, H.M. Hawthorne, Y. Xie, Wear rates and specific energies of some ceramic, cermet and metallic coatings determined in the Corrolis erosion tester, Wear, vol. 233-235, pp. 319-327, 1999, doi: 10.1016/S0043-1648(99)00213-6

[50] J. Singh, S. Kumar, S.K. Mohapatra, Tribological analysis of $\mathrm{WC}-10 \mathrm{Co}-4 \mathrm{Cr}$ and $\mathrm{Ni}-20 \mathrm{Cr}_{2} \mathrm{O}_{3}$ coating on stainless steel 304, Wear, vol. 376377, pp. 1105-1111, 2017, doi: 10.1016/j.wear.2017.01.032

[51] M. Ramachandra, K. Radhakrishna, Effect of reinforcement of fly ash on sliding wear, slurry erosive wear and corrosive behavior of aluminum matrix composites, Wear, vol. 262, 
iss. 11-12, pp. 1450-1462, 2007, doi: 10.1016/j.wear.2007.01.026

[52] M. Abedini, H.M. Ghasemi, Synergistic erosioncorrosion behavior of Al- brass alloy at impingement angles, Wear, vol. 319, iss. 1-2, pp. 49-55, 2014, doi: 10.1016/j.wear.2014.07.008

[53] H.M. Ghasemi, M. Karimi, A. Pasha, M. Abedini, Erosion-corrosion behaviour of 316-SS in seawater simulated Environment at various impingement angles, International journal of Mechanical Material Engineering, vol. 6, no. 3, pp. 400-404, 2011.

[54] G.T. Burstein, K. Sasaki, Effect of angle on the slurry erosion- corrosion of 304 L stainless steel, Wear, vol. 240, iss. 1-2, pp. 80-94, 2000, doi: 10.1016/S0043-1648(00)00344-6 